Florida International University

FIU Digital Commons

\title{
Making History: The Sephardi Jewish Orphans of Sao-Tome and the African -American Appropriation of their Story
}

Arinze D. Amanfo

Florida International University, aaman006@fiu.edu

Follow this and additional works at: https://digitalcommons.fiu.edu/etd

Part of the Religion Commons

\section{Recommended Citation}

Amanfo, Arinze D., "Making History: The Sephardi Jewish Orphans of Sao-Tome and the African -American Appropriation of their Story" (2019). FIU Electronic Theses and Dissertations. 3960.

https://digitalcommons.fiu.edu/etd/3960

This work is brought to you for free and open access by the University Graduate School at FIU Digital Commons. It has been accepted for inclusion in FIU Electronic Theses and Dissertations by an authorized administrator of FIU Digital Commons. For more information, please contact dcc@fiu.edu. 


\section{FLORIDA INTERNATIONAL UNIVERSITY \\ Miami, Florida}

MAKING HISTORY: THE SEPHARDI JEWISH ORPHANS OF SÃO TOMÉ AND THE AFRICAN-AMERICAN APPROPRIATION OF THEIR STORY

A thesis submitted in partial fulfillment

of the requirements for the degree of

MASTER OF ARTS

in

RELIGIOUS STUDIES

by

Arinze Amanfo

2019 
To: Dean John F. Stack, Jr.

Steven J. Green School of International and Public Affairs

This thesis, written by Arinze Amanfo, and entitled Making History: The Sephardi Jewish Orphans of São Tomé and the African-American Appropriation of Their Story, having been approved in respect to style and intellectual content, is referred to you for judgment.

We have read this thesis and recommend that it be approved.

Erik Larson

Albert Wuaku

Date of Defense March 26, 2019

Tudor Parfitt, Major Professor

The thesis of Arinze Amanfo is approved.

Dean John F. Stack Jr.

Steven J. Green School of International and Public Affairs

Andres G. Gill

Vice President for Research and Economic Development and

Dean of the University Graduate School

Florida International University, 2019 
(C) Copyright 2019 by Arinze Amanfo

All rights reserved. 


\section{DEDICATION}

I dedicate this thesis, to the memory of my late Father Francis Odoemenam Amanfo, my

late Sister Oby Amanfo and to all the wealth of humans, Ani (the ground) and the Sea has swallowed up. 


\section{ACKNOWLEDGMENTS}

I am sincerely grateful to the creator Chineke and the goodwill I have received from the Religious Studies department at Florida International University, particularly the Department Chair. Professor Erik Larson, whose gracefulness fills up an entire room. He literarily planted the seeds of my interest in Jewish studies. I also owe immense gratitude to Professor Tudor Parfitt, my Major Professor, who has always nudged me towards the path of excellence and consistently watered my academic garden with opportunities towards the advancement of my educational pursuit. I also appreciate the guidance, leadership of Dr. Albert Wuaku, who opened the floodgates of African religion and African-Diaspora religions to me. These three Professors believed in this work even when I was not sure how to go about it.

My sincere gratitude to my beautiful wife, who has always stood by me. Your love and support is second to none. You spiced up the duration of my program by giving me one of the greatest gifts in my Son Ikenna Enyinnaya. I also appreciate my brother Ikenna Amanfo and my mother Anne Amanfo who have supported me in many ways I cannot sufficiently explain. My Love and gratitude to my siblings and friends in Miami for the support and encouragement.

Finally, I am appreciative of the staff, Students and Professors of the department of Religious studies. The numerous academic interactions helped shape the content of this work. I am indeed grateful. 


\begin{abstract}
OF THE THESIS
MAKING HISTORY: THE SEPHARDI JEWISH ORPHANS OF SÃO TOMÉ AND THE AFRICAN-AMERICAN APPROPRIATION OF THEIR STORY
\end{abstract}

\author{
by \\ Arinze Amanfo \\ Florida International University, 2019 \\ Miami, Florida \\ Professor Tudor Parfitt, Major Professor
}

This study seeks to explore the little known story of the Sephardi Jewish Orphans of São Tomé. Not much is known about the children who were taken from Portugal to the western coasts of Africa. The story of these 600 Sephardic Jewish children is unique and enigmatic. However, it has been subjected to an unusual interpretation. Notably, many African-Americans have appropriated this portion of Sephardi Jewish history. For some, they have traced their Jewish ancestry to this historical event, and clearly self-identify as Jews based on this narrative. Why do they do this? The theory of Afrocentricity and collective memory is applied to this case study of African-Americans; to consider how they are able to adopt this story as their own. Finally, it is said that nature abhors a vacuum; the lacuna inherent with this story is akin to the historical fate of many African Americans. This study attempts to explore how these two communities, from the past and the present, have come together in the making of history, imagined or real. 
I. INTRODUCTION .........................................................

Statement of the Problem........................................................................ 3

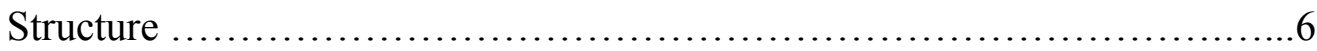

Theoretical perspectives............................................. 7

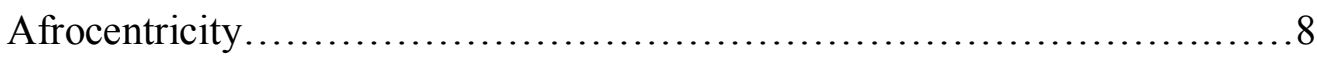

Collective Memory.................................................17

II. LITERATURE REVIEW ............................................. 18

The Sephardic Jews of São Tomé....................................25

Tracing the Lineage of the Sephardic Children of São Tomé...............25

III. DISCUSSION .............................................................. 35

Judaism: From Africa to the World.................................... 35

Colonial Conspiracy and the Justification for Slavery.......................38

Counter Theology as a form of resistance.............................44

African and African-American Judaism: Two peas in one pod..............46

Black Jews in the United States of America.............................49

Who are the Black Hebrew Israelites?......................................................54

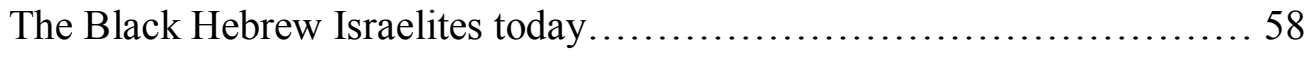

African-American Appropriation and

the Case for a 'Black Inquisition' ........................................ 61 
Biblical Prophecy as Evidence of African-American Jewish Ancestry

IV. CONCLUSION ............................................................. 78

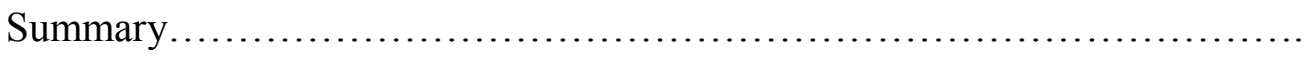

Limitations and Future Directions.

BIBLIOGRAPHY 


\section{INTRODUCTION}

Over the years, there has been a curious tendency for people who already have an identity to feel the need to become Jews. Scholars have identified marriage, conversion or selfidentification as some of the ways people have embarked upon the pursuit of the Jewish identity. ${ }^{1}$ The Jewish Identity has become a phenomenon that resonates with various ethnic groups. In many ways, the story of the Sephardic Jewish Orphans has become relevant in the emergence of Jewish identities in many parts of the world. This story, which began in Spain, through Portugal and then São Tomé, is unique and multi-faceted. The story played out in São Tomé, an island located on the Equator in the Gulf of Guinea, off the west coast of Africa. It is the largest island in what is today know as São Tomé and Principe.

Various African American religious and liberation groups have self-identified as Jews. These groups have come up with claims and counterclaims of some affinity to the Jews and the Israelite nation as a whole. They have appropriated Jewish identity in many ways and have incorporated the story of the orphans of São Tomé into their own narrative. Why did they do this? There are a number of reasons for evoking the little-known history of this small Sephardi community.

The story of the Sephardi Jewish Orphans of São Tomé is a unique one, characterized by separation, kidnapping, forced baptism, conversion, and the loss of heritage. However, despite the distinct nature of this story it will be impossible to reconstruct it in a vacuum. As such, it is imperative to go back in time to piece together specific historical facts that led to this unusual

\footnotetext{
${ }^{1}$ Tudor Parfitt, and Netanel Fisher, eds. Becoming Jewish: New Jews and Emerging Jewish Communities in a Globalized World. (Cambridge Scholars Publishing, 2016), IV.
} 
and painful event. In this case, the story of the Sephardi Jewish Orphans of São Tomé who were forcibly snatched from their parents in Portugal, cannot be reconstructed without reliving the history of the Jews of Spain and Portugal

For hundreds of years, the Jewish community in Spain also known as Sephardic Jews was the largest and most important in the West. They participated in cultural and political life along with their Christian and Muslim neighbors. ${ }^{2}$ Mostly, they persisted in their practice of Judaism in a predominantly Catholic community. With the establishment of the Inquisition and the subsequent expulsion of the Jews from Spain in 1492, thousands of Sephardi Jews sought refuge in Portugal. This arrangement for their stay negotiated with the monarchy involved the payment of a head tax by the Jews.

A large contingent of Sephardic Jewish children, alongside their parents, were part of the people who emigrated to Portugal, but without the means to pay the head tax. Subsequently, the Portuguese king in an act best described as "unaccountable cruelty" ordered the abduction and deportation of nearly 2,000 of these children to the Islands of São Tomé and Principe in Western Africa in a dramatic way, which still resonates today. ${ }^{3}$ The Island of São Tomé at the time was in the process of being colonized by Portugal. ${ }^{4}$

\footnotetext{
${ }^{2}$ Jane Gerber, Jews of Spain: A History of the Sephardic Experience. (Simon and Schuster, 1994), 10.

${ }^{3}$ Ibid, 141.

${ }^{4}$ Steven Lowenstein, The Jewish Cultural Tapestry: International Jewish Folk Traditions (Oxford University Press, 2002), 36.
} 
Many Scholars have identified the use of aspects of Jewish history in the creation of quasi-Jewish identities. According to Tudor Parfitt, "Throughout the world today there are millions of people who are not Jewish by conventional Jewish criteria but who in many cases consider themselves to be Jewish "5Additionally, a recent article estimates that globally there are between 13.5 and 14 million people may be considered as shadow Jews. ${ }^{6}$ These groups, which have been categorized as "emerging Jewish communities,"7 can be found all around the world, particularly in Africa, the United States, and the Caribbean, where Black groups and organizations have metamorphosed into Jewish religious movements while practicing various forms of Judaism.

The histories of these African American Jewish groups are on their own quite complex. They have varying degrees and motivations for their origins and practices. However, they have evolved to a point where they not only appropriate analogies of Jewish history in line with Biblical times but also Jewish history in antiquity and even modern history. This study, therefore, attempts to show and answer the crucial question of how Jewish history, particularly the story of the exile of the Sephardic children has influenced the creation and performance of Jewish identity among African Americans, who are a significant portion of the emerging Jewish communities.

In this study, I argue that history transcends historical boundaries, landmarks and even genetics. It can be fluid and definitely not absolute. Like nature, history finds its way to

\footnotetext{
${ }^{5}$ Parfitt and Fisher. Becoming Jewish : New Jews, 4.

${ }^{6}$ Ibid, 3.

${ }^{7}$ Ibid, 3.
} 
communities who use their peculiar situations and experiences to redefine and remake their perception of history. This study also argues that in the business of appropriation, the similarity in experiences often times leads to the crisscrossing of ideas, which opens the door to various forms of appropriation, either historical or cultural. It is therefore not an aberration for communities to interpret their experiences through the prism of what can be considered history of other peoples, primarily to suit their narratives and otherwise perform their identity projects.

\section{Statement of the Problem}

The fate of the Sephardic Jewish children, exiled in faraway West Africa, has remained speculative. Various scholars have tried to trace their history as well as how and where they eventually settled. Some scholars and scientists have taken the investigation further into the realm of technology to confirm if there is any genetic trace of Sephardic heritage still present in São Tomé, and to ascertain the location of the descendants of those exiled children. ${ }^{8}$

Despite the success of many of these investigations, their conclusions are not specific regarding the eventual fate of the exiled children. Scholars have focused more on the Spanish experience of expulsion and the Inquisition. On the other hand, they have neglected the Portuguese arm of that experience. Besides, historians have mostly relegated the experience of these children to footnotes, without giving adequate attention to the experiences and status of the exiled children. As such, they have become legends and material for folklore.

\footnotetext{
${ }^{8}$ Nogueiro, Célia, Marques, Alves, Cohen-Addad, Amorim, Gusmão, and Alvarez. Exploring Sephardic Lineages in São Tomé E Príncipe., 461.
} 
Equally crucial in what would seem to be a significant development, African American groups such as the Black Hebrew Israelites in America, who make claim to Jewish ancestry, have appropriated and adopted the memory of this event as a part of their Jewish identity creation and performance projects. However, not much has been written about the AfricanAmerican appropriation of this experience. This study, therefore, proposes to piece together available information to account for these Jewish orphans and to demonstrate the role this historical event is playing in the development of Jewish identity for African Americans.

\section{Purpose of Study}

It is important to face the past to be able to shape the future. The consideration of the backdrop of events that preceded the exile of these Sephardic children sheds a light on a dark episode of world history. Particularly the little known story of the Sephardic Jewish Orphans of São Tomé, an event relating to a Trans-Atlantic slave transaction from Portugal to Africa, which happens to be under-reported. It is clear that notwithstanding the lessons, which can be deduced from this historical event, detailed information, concerning it is scarce. Some scholars have also argued that perhaps the small size and short lifespan of these communities' accounts for this lacuna or historians choose to ignore it while focusing on what they presume to be more important Sephardic Diasporas. ${ }^{9}$

Also, many Scholars have identified various forms of appropriation of the Jewish identity all over the world. This includes the Igbo of Nigeria, who have vehemently held unto an IgboJewish identity, the House of Israel of Sefwi Wawso of Ghana, the Beta Israel of Ethiopia, the Lemba of Botswana and the Abayudaya of Uganda whose ancestors had already adopted forms of

\footnotetext{
${ }^{9}$ Toby Green, Further Considerations on the Sephardim of the Petite Côte, (History in Africa 32, 2005): 165-183.
} 
Judaism around a hundred years ago. ${ }^{10}$ The list of groups appropriating Jewish history and culture in their attempt to align with some Jewish ancestry is endless, leading to evidence of various forms of hybrid identification project. In a world fast becoming a global village, the appropriation of this history by the African Americans has become of great significance.

According to James Landing, the inability to capture the story of Black Judaism can lead to a potential misunderstanding of the historical relationship between the black mobilizations of Christianity and Islam. ${ }^{11}$ This study will, therefore show how the story of the exile of these Sephardic Jewish Orphans has influenced the creation and performance of Jewish identity among African Americans. It will also attempt to use various African American narratives as a watershed in recognizing the intellectual concept of Afrocentrism and collective memory in the appropriation and reconstruction of Jewish history.

\section{Structure}

Section Two will establish the historical background of this study through a review of literature encompassing the circumstances that led to the Inquisition, which necessitated the movement of some Spanish Jews to Portugal as well as the circumstances, which account for the separation of Sephardic Jewish children from their parents, and the eventual exile of the children. It will further attempt to explore the experiences of these Sephardic orphans in light of the Atlantic journey to West Africa, which they embarked on as well as their lives in São Tomé.

\footnotetext{
${ }^{10}$ Parfitt and Fisher. Becoming Jewish, 4

${ }^{11}$ Edith Bruder, and Tudor Parfitt, eds. African Zion: Studies in Black Judaism. (Cambridge Scholars Publishing, 2012), 281.
} 
Chapter Three will discuss the emergence of African American Jewish groups as well as the African links with Black Judaism. It will also examine the various appropriations of the story of the Sephardic Orphans of São Tomé by the Black Hebrew Israelites of America. Chapter Four will provide concluding remarks as well as offer suggestions for further research.

\section{Methodology}

This study employed a historical approach by consulting available primary and secondary sources. The sources used for the reconstruction of this story helped in offering an overview of the history of the Jews of Spain and Portugal and the events that led to their expulsion and the eventual abduction of the Sephardic Jewish orphans.

The research design also deployed the consideration of Afrocentricity as a theory of social change in the appropriation of Jewish History by African-Americans, particularly the Black Hebrew Israelites of America. It also engaged the theory of collective memory in examining and understanding the appropriation of this portion of Sephardic history, by AfricanAmericans, particularly the Black Hebrew Israelites. The study followed Alon Confino's hybrid method, which aims to restructure the connotation of a particular collective memory by utilizing an interwoven strategy that places it within a global historical context and symbolic universe. This hybrid method also utilizes the analysis of the practices, values, and ideas that are symbolized by its specific descriptions ${ }^{12}$

In this connection, this study will focus its attention on how African Americans collectively appropriate the memory of this history to suit their socio-political projects. Evidence

\footnotetext{
${ }^{12}$ Alon Confino, Collective memory and cultural history: Problems of method, (The American historical review 102 , no. 5,1997$): 1391$.
} 
of this appropriation will be garnered from selected media sources that point towards literature and historical data, which they use as foundational references to back up their appropriation and create a Black -Jewish identity in an around the United States of America. Other sources will include journal databases, the library catalog, subject-specific professional websites, and newspaper databases.

\section{Theoretical Perspectives}

While identity may be fixed and trans-historical, on the one hand, it can also be fluid and contingent on the other hand. ${ }^{13}$ It is continually changing and transforming within the historical, social, and cultural developments and practices. The realities of globalization, modernity, postcolonization, and technology have helped shape the idea of identity as a whole. ${ }^{14}$ This may appear to be a simple matter, upon a cursory glance. Particularly if considered from the perspective that everyone is supposedly born with an identity. It even gets more complex and complicated when a generation is born without a concrete idea of their heritage, religion, and identity. More so, when the identity they claim appears to be influenced by others. From this point, there portends a slippery slope if not handled properly.

The case of the African-Americans who have continuously been on a quest for selfdefinition due to the distasteful history of the Trans-Atlantic slave trade is instructive. In this case, as mentioned earlier, the Jewish identity somehow has permeated the culture and practices of the African American society, which has led to the emergence of hybrid Jewish identity.

\footnotetext{
${ }^{13}$ Farah Ibrahim and Heuer Jianna, Cultural and social Justice Counselling, (Springer, New York, 2016), 8-61

${ }^{14}$ Mustafa Koc., Cultural identity Crisis in the age of Globalization and technology, (Turkish Online Journal of Educational Technology-TOJET, 2006), 37-43.
} 
Surprisingly this hybrid identity has led to various appropriations of Jewish history, utterly distinct from popular Black Jewish analogies, mostly tilting towards ancient Israel and the lost tribes of Israel narrative.

While the fluid and ever-changing notion of identity is understandable and best describes the African-American Jewish identity phenomenon, the following theoretical perspectives will aid in understanding this phenomenon from both sociological and psychological perspectives. While this study does not condemn or dismiss the underlying intention of previous scholarship on the subject, it however, attempts to consider the subject of identity appropriation from an Afrocentric perspective and through the ideological prism of collective memory, particularly in the African-American appropriation of the story of the Jewish Orphans of São Tomé.

\section{Afrocentricity}

The idea of Afrocentricity or 'Afrocentrism' as some scholars refer to it is a concept or method popularized by Molefi Kete Asante, an African-American Scholar. Originally, referred to as "black perspective" which referred to the ability to look at information from a different prism, particularly a black point of view other than the widely accepted white perspective. Although Pioneers such as Kenneth Dike of the University of Ibadan Nigeria and Cheikh Anta Diopa Senegalese historian and anthropologist previously initiated the Afrocentric idea, however, the term Afrocentricity made popular by Asante, refers to a way of looking at available information from a black or African perspective. According to Asante, Afrocentricity means, "placing African ideals at the center of any analysis that involves African culture and 
behavior. ${ }^{15}$ It also connotes the penetration of the African customs and culture into the history, behavior, and culture of Black people around the world. ${ }^{16}$

Afrocentricity conceptualizes the ability to see history and various cultures of the world from several angles, which may lead to the creation of hybrid realities. Asante argues that it is by the creation of another reality among other things, that an African can radically assess a given reality. ${ }^{17}$ It can be said that Afrocentricity is in itself in opposition to the wholesome consumption of partial reality. On the premise that whatever is perceived as reality has always been considered from a particular prism. Therefore, Afrocentricity is a concept that opens up the mind of the African who ordinarily should critically assess history, culture, politics or anything that addresses or pertains to him as a black person. The ability to assess these issues leads to the Afrocentric push to disregard a Eurocentric narrative or worldview while re-assessing these issues from an Afrocentric perspective.

Eurocentric ideas place European/American culture as the center of the universe, a sort of standard from which every other culture and history is measured and assessed. For Asante, unless these ideas are dispensed with, African historical and cultural perspectives will not be considered. Asante posits that Eurocentric interpretations do not recognize the African classical thought or past but is more concerned with a discontinuous history and a future that is uncertain. These Eurocentric ideas attempt to separate the African-American and other Africans in the Americas from their African past and cultural heritage, which has substantiated depth.

\footnotetext{
${ }^{15}$ Molefi Asante. Afrocentric idea revised. (Temple University Press, 2011), 1, 2.

${ }^{16}$ Durrenda Ojanuga, The Ethiopian Jewish experience as blacks in Israel, (Journal of Black Studies 24, no. 2, 1993): 149.

${ }^{17}$ Asante, Afrocentric idea revised, 1, 2.
} 
Eurocentric ideas present the African-American culture as distinct from Africa, which can cause severe inter-cultural conflict as orchestrated by the Eurocentric perspective. ${ }^{18}$

The theory of Afrocentricity, therefore, enables the African or non-African to break off the shackles of a supposedly imposed universal perspective, while opening the discourse of cultural and historical assessment to various perspectives, particularly from an African standpoint. Asante argues that history and culture are always assessed from a particular standpoint. He, therefore, proposes the African standpoint instead of the usual Eurocentric perspective, which has always dominated the notion of discourse of the world, excluding Asia and Africa. According to Asante:

The combination of the European centuries provides us about four to five hundred years of solid European domination of intellectual concepts and philosophical ideas. Africa and Asia were subsumed under various headings of the European hierarchy. If a war between the European powers occurred, it was called a World War, and the Asians and Africans found their way on the side of one European power or the other. There was this sense of assertiveness about European culture that advanced with Europe's trade, religious, and military forces. ${ }^{19}$

For Asante, Afrocentricity is a model that is based on the notion that in order for Africans to achieve sanity, they need to reaffirm a sense of action. He, therefore, proposed the Afrocentric idea as a solution to insanity and "a constructural adjustment to black disorientation, decenteredness, and lack of agency. ${ }^{20} \mathrm{He}$ succinctly puts it thus, "No longer are we looking

\footnotetext{
${ }^{18}$ Asante, Afrocentric idea revised, 11.

${ }^{19}$ Molefi Asante, "De-Westernizing communication: Strategies for neutralizing cultural myths, (Routledge, 2010), In De-Westernizing Communication Research, pp. 34-40.

${ }^{20}$ Molefi Asante, Afrocentricity, 2009, http://www.asante.net/articles/1/afrocentricity/.
} 
whitely through a tunnel lit with the artificial beams of Europe," ${ }^{21}$ Thereby discarding the Eurocentric perspective.

Despite the success of Afrocentricity as a theory, some scholars do not align with Asante's scholarship and approach on the subject. Notable of such critics are Mary Lefkowitz and Anthony Kwame Appiah. According to Lefkowitz in her book 'Not out of Africa,' she argues that Afrocentric ideas deprived students of the ability to distinguish facts from fiction and myth from history. She posited that Afrocentric ideas where an egregious attempt to distort history in the most unpleasant ways which were aimed at division rather than the real purpose of history which is to promote the understanding of the world and the past. ${ }^{22}$

Lefkowitz attempts to deconstruct the racial Afrocentric appropriation of specific popular historical figures such as Cleopatra and Socrates, which presents them as Blacks. ${ }^{23}$ She also posits that these ideas pose a threat to rational tradition and dismisses them as "competitive plausibilities" and falsified history without evidence. ${ }^{24}$ She argues that Afrocentrists simply appeal to their emotions by claiming that Greek heritage was stolen from their ancestors, by giving credit for achievements originally by the Greeks to Africans. ${ }^{25}$ For her, this idea of a stolen legacy is not only fallacious but deprives the African people of truly knowing their

\footnotetext{
${ }^{21}$ Molefi Asante, Afrocentricity, (New Jersey, 1988), 1.

${ }^{22}$ Mary Lefkowitz, Not Out of Africa, How Afrocentrism Became an Excuse to Teach Myth as History. (Harper Collins, New York, 1996), 8.

${ }^{23}$ Ibid, 157.

${ }^{24}$ Mary Lefkowitz "Not out of Africa, revisited." The Times Literary Supplement, 20 June 1997, p. 15+. The Times Literary Supplement Historical Archive, http://tinyurl.galegroup.com/tinyurl/8jDsX5. Accessed 9 Jan. 2019.

${ }^{25}$ Mary Lefkowitz. "Afrocentrism poses a threat to the rationalist tradition. (Chronicle of Higher Education 38, no. 35, 1992), A52-A52.
} 
historical contributions to civilization and society. ${ }^{26}$ She calls teaching such falsified ideas a sanction of falsehood.

Worthy of note, however, is the fact that Lefkowitz to a significant extent alluded to a Eurocentric manipulation of historical facts by claiming Greek achievements, conceding to Asante's assertion on this point. However, she swiftly accuses Afrocentrists of attempting to do the same thing. In her own words, "Although it is understandable that Afrocentrists as certain Europeans have done before them, should want to take credit for the ancient Greek origins of western civilization - There is no reason why claims of a conspiracy should be credited if no real evidence can be produced to support it." 27 She, therefore, accuses Afrocentrists of peddling historical data of black achievements without any substance. Supporting Lefkowitz perception of Afrocentrists and Afrocentrism, George will consider the idea unscholarly. He believes that:

Afrocentrism is sometimes based on merely incompetent interpretations of facts, but more often is based on aggressively meretricious misrepresentations of facts for ideological purposes. They are the purposes of identity politics, which preaches that in arguments about history, the important thing is not the historians' motives, which are explained by racial or ethnic determinism. ${ }^{28}$

Similarly, Kwame Appiah dismisses the theory of Afrocentricity, to the extent that it attempts to replace Eurocentrism with the self-same approach it claims to dislike. He argues that this form of Afrocentricity as popularized by Asante, smirks of a peculiar form of anti-Semitism, which places all the blame of black suffering and discrimination on a supposed Jewish conspiracy. He describes this Afrocentric turn as "a composite of truth and error, insight and illusion, moral

\footnotetext{
${ }^{26}$ Lefkowitz, Not out of Africa, revisited." The Times Literary Supplement Historical Archive, http://tinyurl.galegroup.com/tinyurl/8jDsX5. Accessed 9 Jan. 2019.

${ }^{27}$ Lefkowitz, Not Out of Africa, 8 .

${ }^{28}$ George Will, Intellectual Segregation: Afrocentrism's Many Myths Constitute Condescension towards AfricanAmericans, (News Week, 1996): 78.
} 
generosity and meanness." He further argues that the idea of Afrocentricity falls on its head being that it attempts to fall into the same trap of the ills of accusations of Eurocentrism by attempting to replace these supposed ills with another one-sided standpoint. ${ }^{29}$

Other scholars have lent their voices to the Eurocentric and Afrocentric debate, and a plethora of attempts have been made to revise and clarify the real intent of the concept. Some insist that, Afrocentricity does not deny the existence of other cultures and their achievements on their own merit, but that African history should be perceived in the proper perspective and their achievements should not be continuously downplayed. ${ }^{30}$ Chidozie Chukwuokolo, in his defense of the concept, posited that :

Afrocentrism, which means African centeredness, does not violently confront any person or people but is a resolute attempt to put the records right. It is about placing African people within their historical framework. It is a demand that the contributions of Africans in all areas of civilization be reflected in world history. ${ }^{31}$

Others have argued that Afrocentricity should not be perceived as a "reactionary response to Euramerican cultural domination," rather it should be considered as a theory of social change whose main objective is to turn the sociological and historical discourse on blacks around, from the depiction of blacks as objects rather than subjects. ${ }^{32}$ For Africans to be perceived "as agents, actors, and participants rather than as marginals on the periphery of political or economic experience. ${ }^{33}$ Henry Louis Gates, however, identifies that while the impulse to consider African-

\footnotetext{
${ }^{29}$ Anthony Appiah, In my father's house: Africa in the philosophy of culture. (OUP, New York, 1993), 23-24

${ }^{30}$ Midas Chawane, The development of Afrocentricity: a historical survey, (Yesterday and Today, Johannesburg, 2016), 83.

${ }^{31}$ Chidozie Chukwuokolo, Afrocentrism or eurocentrism: The dilemma of African development, (OGIRISI: A new journal of African Studies 6, no. 1, 2009) 24-39.

${ }^{32}$ George, J., and Sefa Dei, Afrocentricity: A cornerstone of pedagogy, Anthropology \& Education Quarterly 25, no. 1, 1994), 4.

${ }^{33}$ Asante, Afrocentricity, http://www.asante.net/articles/1/afrocentricity/,
} 
American studies from the African's prism of discovering a lost heritage, the scholar should be careful to avoid the highway of becoming a polemist. ${ }^{34}$

The theory of Afrocentricity best suits and helps in understanding and conceptualizing a significant portion of African-American culture. This concept places Africa as the center and standpoint for discourse in history, politics, economics, and religion. Which is why rhetoric such as "Black Revolution," Marcus Garvey's back to Africa and Kwame Ture's black power constantly resound within the African-American community. Asante calls these reverberations,' rhetoric manifestations,' which to him, answer the African-American question of identification and how blacks have reacted to the problems of integration in the American society and disconnection from their African past, heritage and identity. ${ }^{35}$

Other Afrocentric ideas, which have become part of the African American community, include mythmaking. These myths, which set blacks at the center of their creation, were developed by African-Americans as a way to adapt to circumstances in history, which they were exposed. These myths represent the African's responses to their presence in the Americas, which reflect similar conditions, which must be perceived in their own "fundamental contexts. ${ }^{36}$ According to Asante:

In the language of the African American speaker: myth becomes an explanation for the human condition and an answer to the problem of psychological existence in a racist society-Perhaps the African American version is truncated by Christianity or Islam or some other non-African mythic expression, but even in modified form we see how ancestral myths are a part of our communicative sense-The idea of hope and possibility

\footnotetext{
${ }^{34}$ Bracey, Earnest N. Prophetic Insight: The Higher Education and Pedagogy of African Americans. (University

Press of America, Maryland, 1999).80.

${ }^{35}$ Asante, The Afrocentric Idea, 162.

${ }^{36}$ Ibid, 110.
} 
rises on the shoulders of an imaginative African American mythology that sees the future as brighter than the present. ${ }^{37}$

African Americans in tune with the contextualized Afrocentric idea also created and sustained Afrocentric analogies of suffering, both hypothetical and historical in nature. In line with these Afrocentric mythological ideas, these perspectives are attributed to the fact that the African American views victory in a political context as being based upon their history of suffering. As a result, converting the suffering of the past into a victorious consciousness become the focus of an entire Afrocentric school of literary thought. ${ }^{38}$ The case of the appropriation of portions of Jewish history epitomized by the suffering and disillusionment, particularly of the Spanish Inquisition and the story of the Sephardic Orphans of São Tomé is therefore instructive.

African Americans therefore created a way to psychologically counter the pain and suffering, which they had encountered. Most of the African American pioneers, who propagated the Hebraic message alongside an African Jewish identity and ancestry, were exposed to slavery, either as children or through their parents. Notably, most of them experienced first-hand the harsh effects of racial segregation and discrimination occasioned by the Jim Crow laws of the 1800s and the 1900s. Their ability to react through various forms of appropriation sterns from their sense of a shared experience of suffering from the Jews and a consequent identification with the biblical and historical characters available to them.

This is therefore not particularly strange; neither is it unique to the African Americans. The history of the Haitians who immediately appropriated Catholic saints and images as their own, to represent their various African gods and deities comes to fore. In circumstances like this,

\footnotetext{
${ }^{37}$ Asante, The Afrocentric Idea,, 110,111,112.

$38 \mathrm{lbid}, 115$
} 
the concept of Afrocentricity aids in understanding the African world view in the context of the events and imagery around the African. Therefore, while a French colonist in Saint Domingue sees the picture or depiction of Saint James on a horse wielding a sword, the African sees the Iron element used in making the sword and quickly appropriates that Image to become Ogun, the god of iron in the Yoruba African religion.

The African subsequently seeks out unique ways to validate this Afrocentric vision. In the case of the story of the Sephardic Orphans, many African Americans did not need to look too far to validate these historical characters. They simply adopted various Afrocentric materials already circulating at the time. Although these materials were not originally meant for them as Parfitt identifies, they were ready-made meals, quickly consumed and internalized to suit the psychological state of the African American as a panacea for insanity, which Asante identified earlier. ${ }^{39}$

In the same light, while the African reads or is told of a story in the Bible or some character in Jewish history. He weighs the situation these characters went through against his own lived experiences and re-interprets these stories to suit his peculiar situation. The mention of Ethiopia and Egypt and their relationship to ancient Israel in the Bible, which was available for African American consumption, was internalized and even practiced by a significant number of African Americans who harped upon the opportunity to emigrate to Africa.

Similarly, the story of the Sephardic Orphans and their ties to Africa made more sense in the African American self-identification project. The story of the Sephardic orphans, although not palatable, resonated with the African Americans who claimed Jewish ancestry. Like

39 Tudor Parfitt, Black Jews in Africa and the Americas, (Massachusetts, Harvard University Press, 2013 ), 80. 
Abyssinia (Ethiopia) and Egypt in the Bible, the story of the Sephardic Orphans of São Tomé in Africa, which was part of Jewish history was used to validate their claims to Jewish ancestry. For many African Americans whom the Bible had influenced, they harped on this narrative to justify their Jewishness. This story presented an opportunity to relive history by African Americans, with Africans not just as mere observers, but also as active participants in the course of history and civilization. This story was, therefore, a branch, which African Americans used to plug themselves into the stem of world history and civilization

\section{Collective Memory}

Although the existence of a single national collective memory cannot be disputed, the power of memory in forging group identities must be recognized. ${ }^{40}$ One key theme prevalent in this study is the demonstration of the appropriation of the story of the Sephardic Orphans of São Tomé by various African-American groups claiming Jewish ancestry. Specifically, the appropriation of their narrative, which has led to the creation of African-American Jewish identity. Notably, the Black Hebrew Israelites, a group whose collective memory of an African Jewish Past, has permeated into their culture, practices, and identity. It is also imperative to state that this appropriation by the Black Hebrew Israelites is not solely based on the motivation for the construction of Jewish identity, but also for pushing a political agenda in line with the Black power school of thought. The Black Hebrews, therefore, seem to be appropriating this Jewish historical experience of abduction as lenses or mirrors through which they connect genealogically to a Jewish heritage.

\footnotetext{
${ }^{40}$ Aletta Norval, Memory, identity and the impossibility of reconciliation: The work of the Truth and Reconciliation Commission in South Africa, (Oxford, Blackwell Publishers Ltd, 1998): 250
} 
Various scholars from a plethora of disciplines have discussed the theory of collective memory. ${ }^{41}$ This had led to various interpretations of the term and has been used to understand various cultures and practices. For this study, the theory of collective memory is considered from the standpoint of Maurice Halbwachs who is often described as the father of collective memory studies. ${ }^{42}$ For Halbwach, the human mind tends to reconstruct its memories under the pressures of society. For him, it is not strange then that society causes the mind to transfigure the past to the point of yearning for it. ${ }^{43}$ Oren Stier accurately captures the meaning of the term particularly in the context of this study. He states that collective memory "refers to a common, shared awareness of the presence and meaning of the past in a particular contemporary context, delimited and determined according to certain conditions." ${ }^{44}$

Various scholars have dismissed Halbwach's analysis of collective memory, condemning same for placing history in opposition to memory. They have also argued that memory that does not emanate from history is considered dubious. ${ }^{45} \mathrm{Noa}$ Gedi and Yigal Elam also criticized this approach to memory, which treats it as if it were a living entity or an ongoing project that can only be appropriated by the individual in line with his contemporary perspectives. They argue that the idea of interpreting memory of the past based on the present simply encourages misrepresentations and can lead to deterioration and disintegration of historical based facts.

\footnotetext{
${ }^{41}$ James Wertsch, Voices of collective remembering. (Cambridge University Press, 2002), 33.

${ }^{42}$ Ibid, 19.

${ }^{43}$ Maurice Halbwachs, On collective memory, (Chicago, University of Chicago Press, 1992). 51

${ }^{44}$ Oren Stier, Memory Matters: Reading Collective Memory in Contemporary Jewish Culture, (Indiana University Press, 1998), 69,70.

${ }^{45}$ Pierre Nora, Between memory and history: Les lieux de mémoire, representations (1989), 8.
} 
Some others have dismissed this argument, positing that the treatment of history as gospel and memory as false does a great disservice to both history and memory. According to Stier, "collective memory is not a self-contained domain. It progresses alongside intentional and planned activities of social and political agencies, and is nourished through memories of individuals." 46 For Stier, Memory is dynamic and is continuously renegotiated. Most likely, this renegotiation is also the function of myth, which is real and a narrative of the past, and the process that brought forth the present. He also states that myths successfully encourages societies towards the consolidation of social groups in the bid to achieve an unending desire for selfdefinition. ${ }^{47}$

Some other Scholars choose to be in between the negotiation between memory and history, clearly deferring to accurately drawing from both ideas. According to Yael Zerubavel, they both tend to be social constructs, whose inspirations are drawn from available historical records and are highlighted or downplayed respectively in the bid to suit current socio-political agendas and experience. She argues that in the process of going to back to these records, the tendency to re-interpret the events, which were recorded to suit the readers' worldview, is very likely, thereby re-contextualizing the records. ${ }^{48}$

This perspective of the constant renegotiation of selected memories will be discussed in section three of this work, which identifies how African-Americans willingly harped on the idea of the 'Lost tribes of Israel' as their story and link to Jewishness. This study will also discuss how this narrative has contemporarily switched to a more recent appropriation of the story of the

\footnotetext{
${ }^{46}$ Wertsch, Voices of collective, 19-21.

${ }^{47}$ Stier, Memory Matters: Reading Collective Memory, 68.

${ }^{48}$ Ibid, 5.
} 
Sephardic Orphan's experience, and subsequently to being not only the Sephardic Orphans themselves but also the Sephardim identity and victims of the Inquisition.

Despite the many condemnations of Halbwach's theory, it is put forward that it best describes the traces of cultural practices and identity between groups that historically do not have any connection. One factor that many of these scholars fail to consider is the fact that history in itself is not sacrosanct and as such not immune from criticism. On the other hand, some other scholars have harped upon Halbwach's analysis of collective memory and subsequently highlighted specific strong values, which can be gleaned therein.

Scholars such as Wentsch, have identified what he calls 'The Distributed Version of Collective Memory' in which like history, textual memory also serves as a resource for collective memory. ${ }^{49}$ According to John Gardener, Collective memory includes "those in which we are aware of, the knowledge that we possess but in a more impersonal way." ${ }^{50}$ For Wentcht, "a coherent account of collective memory can be based on notions of knowledge of texts. ${ }^{51}$ According to Halbwach:

We preserve memories of each epoch in our lives, and these are continually reproduced: through them, as by a continual relationship, a sense of our identity is perpetuated. However, precisely because these memories are repetitions because they are successively engaged in very different systems of notions, at different periods of our lives, they have lost the form and appearance they once had. They are not intact vertebra of fossil animals, which would in themselves permit reconstruction of the entities, which they were once a part. ${ }^{52}$

\footnotetext{
${ }^{49}$ Wertsch, Voices of collective, 21.

50 Ibid, 27

51 Ibid, 27.

${ }^{52}$ Halbwachs, On collective memory, 47.
} 
Halbwach's perspective in this regard best suits the case of African-Americans. It will be discussed in Chapter Three of this work, how they drew inspiration of their Jewish identity from African connections, such as the Igbo of Nigeria and the Falasha of Ethiopia. Unknown to them, this had more to do with colonial conspiracy and manipulation of the colonized, than with genealogy and actual Jewish origins.

It is also imperative to note that the case of African American Jewish groups is not unique in this business of appropriation. The appropriation of the principles of the Rastafari movement from Jamaica to far away New Zealand is equally essential. According to Edward Douglas and Ian Boxill:

Maori commitment to Rastafari is further noteworthy because it is essential. Afrocentrism has been rejected and placed in a New Zealand context. Aoteroa Rastafari have accepted Rasta identity in response to life crises caused by the power of Anglo-Celtic assimilation politics and culture and the conflict of identity that has arisen as a result. As Rastafari, Maori in Aotearoa have a sense of belonging to and identifying with a wider group of similar people. ${ }^{53}$

Similar to Black Hebrew African American groups whose appropriation is connected to the echoes of Trans-Atlantic slavery and the discrimination they faced, alongside the quest for selfdefinition. The presence of bouts of war and diseases led to growing economic marginalization of the Maori, which crystallized to a cultural and religious appropriation of the Rastafari identity. It is noteworthy that the Rastafari movement in Aotearoa took its root "without direct or sustained contact with other Rastafari. ${ }^{54}$ It was merely a form of resistance precipitated by the crisis in New Zealand.

\footnotetext{
${ }^{53}$ Barnett, Michael. Rastafari in the new millennium: A Rastafari reader. (Syracuse University Press, 2014).36

${ }^{54} \mathrm{Ibid}, 36,338$.
} 
According to Halbwachs, we often consider ourselves the originators of feelings, views, desires, and notions inspired by others. This is mostly dependent on our agreement with the content of the assertions presented that we accept in unison as the sources of our perceptions. ${ }^{55}$ Ibrahim and Ohnishi put it succinctly:

Identity is influenced by positive or negative experiences in a social setting, especially for marginalized individuals, identity can get facilitated, or compromised. It is possible for identity to evolve to higher levels of functioning despite challenging life experiences; and the social construction of race, and the history of slavery, segregation, exclusion, and the negative sociopolitical history of a nation can negatively influence identity development with race-related trauma and stress over several generations. ${ }^{56}$

This, in no small extent aids in understanding the influence of Jewish Identity in African American religious groups and their claims to Jewish identity.

These Jewish Echoes were not only groomed as a result of the discrimination and slave experiences in the Americas, but also an identity formed by colonist's inspired texts, written by both Africans and non-Africans concretizing the presence of black African Jews in Africa. According to Jacob Dorman:

Culture is similarly dematerialized and airborne, spread by itinerant preachers, by hucksters, by sailors and railroad workers, by advertising, by newspapers, pamphlets, and books, by traveling tented circuses, and by temporary tested revivals. Like seeds carried by little more than wind, new cultural innovations often spread through means that are more ideational than material, and almost entirely disconnected from ancestry. It is not that people don't pass along cultural memes 'vertically' to their children; of course, they do. But people also pick up culture more obliquely or 'horizontally' from the playground and the street; from books, mass media, and dancehalls, and from that vast primordial soup of the Black Atlantic Dialogue, a source bounded by heredity. ${ }^{57}$

\footnotetext{
${ }^{55}$ Wertsch, Voices of collective, 22.

${ }^{56}$ Farah Ibrahim and HeuerJianna, Cultural and social justice counseling, (New York, Springer International Publishing, 2016) 15

${ }^{57}$ Jacob Dorman, Chosen People, (Oxford University Press, 2016), 7.
} 
The seed of Jewish identity for African Americans was sowed long ago and can be traced to Africa. African American Jewish groups who have held unto various portions of Jewish identity and history have also developed into a religious movement on their own. Their various forms of appropriation will be elaborately discussed in section three of this work will also include how portions of the bible are being used to justify what can be described as the black Inquisition, particularly the Sephardic abduction experience from Portugal to São Tomé.

This chapter, however, discussed identity as a fluid subject. It addressed the trans historical nature of how people perceive themselves, either as individuals or as a group. It also considered the theory of Afrocentricity and Collective memory to examine the ever-changing phenomenon of identity. Although various scholars have challenged the use of these theories, this Chapter made a strong argument for reconsideration regarding why people go the extra mile to self-identify with another group. It also identified the role of personal and group experiences play in the formation of cultural identity. In this case, these theories help to understand why some African Americans would feel the need to self-identify as Jews, through either appropriation or the reconstruction of a distant memory, either real or imagined. 


\section{LITERATURE REVIEW}

\section{The Sephardic Jews of São Tomé}

This chapter discusses the historical background of the Jews of Spain and Portugal. An over view of their status and conditions in the Iberian Peninsula will be examined. It will attempt to trace the geographical and experiential trajectory of the Sephardic Jewish Children from Spain, through Portugal and then São Tomé. The historical perspectives of other Scholars and historians regarding these Orphans will be discussed in this chapter. It will also account for their lives on the little known Island of São Tomé in West Africa, as well as the possibilities of their emigration to other parts of the world.

The Sephardim who had lived in Spain for many years went through different conditions under Christian and Muslim monarchs. Some of them adapted quickly to the wave of the religious practices of the various Kings of Spain. This ability to adapt quickly soon endeared them to the nobles and Kings. In many cases, they were very influential and soon became part of the advisers of the Kings. In other cases, this led to a rising animosity against the Jews of Spain, which led to general indignation and subsequent pogroms against them in 1391. According to Moccatta, about 4,000 Jews fell victim to the onslaught. ${ }^{58}$ Many Jews, therefore, were forced to leave Spain or to convert to Christianity. Those who converted and referred to as New Christians were yet again suspected of surreptitiously practicing the Jewish religions. The circle of animosity and violence against the Sephardim was therefore ignited from this point.

\footnotetext{
${ }^{58}$ Frederic Mocatta, The Jews of Spain, and Portugal, and the inquisition, (Longman's Green and Company, 1877), 17.
} 
The Majority of the Jews from Spain fleeing the Inquisition and expulsion emigrated to Portugal. They choose Portugal with the hopes for a better life and perhaps toleration. It is important to note that there were Jews already living in Portugal. However, the Jews of Portugal fared a lot better than their counterparts in Spain did. Although they were also relegated to their quarters and made to wear stipulated apparel, they were allowed to conduct their religious affairs themselves. ${ }^{59}$ Unfortunately, they soon suffered a similar fate, when the Jews of Spain joined them upon their expulsion from Spain.

Before this expulsion, King John II had allowed the Jewish refugees to remain in Portugal. The arrangement for their stay was negotiated with the Monarchy. This involved the payment of a head tax or 'coima' by the Jews. By 1493, many of these refugees could not pay this ransom. Perhaps this was due to the short ultimatum given to them by the Spanish Monarchy, which impoverished many of them. Gerber narrates that alongside the payment of an expensive tax, the King gave an eight-month-long reprieve period to allow the Jews to stay. Upon the expiration of this period, the King accused them of non-fulfillment of their part of the negotiation. ${ }^{60}$

According to Garcia de Resende, the official chronicler of King John II, in 1493, those who refused to convert and could not pay the stipulated fee, had their children taken away from them, baptized by force, and deported to São Tomé. They were forcefully baptized so they could be raised as Christians and help populate the island that the King had just leased to Alvaro de

\footnotetext{
${ }^{59}$ Mocatta, The Jews of Spain and Portugal, 23.

${ }^{60}$ Gerber, The Jews of Spain, 141.
} 
Caminha at an annual rent of 100,000 reis. ${ }^{61}$ The island of São Tomé was uninhabited at the time of its purchase in 1470 by the Portuguese crown. However, it was a fertile land, which needed cultivation. The expulsion and subsequent enslavement of these children were likely orchestrated to meet what appeared to be an opportunity for the crown to populate and exploit the fertile land to benefit Portugal. ${ }^{62}$

Before the expulsion of the Sephardic children, Caminha had been empowered to populate the land by other means. He had sent condemned criminals, who were called 'degredados', prostitutes and other laborers to help populate and cultivate the land. However, he needed more hands. According to Garfield, this was not the real reason the King ordered the abduction of the Sephardic children. The supposed enforcement of religious purity was what drove his hand to make such a decision ${ }^{63}$

Resende posited that the fate of these children and how they fared in São Tomé is unknown. However, he alluded that the success of the Island as a thriving sugar base has been traced to the talents of the descendants of these children. Other Sources narrate the story a bit differently, however with innuendos and apparent exaggerations. According to Samuel Usque, the Portuguese Jewish Chronicler:

The island of São Tomé had recently been discovered. It was inhabited by lizards, snakes, and other venomous reptiles, and was devoid of rational beings. Here the king exiled condemned criminals, and he decided to include among them the innocent children of these Jews. Their parents had seemingly been condemned by God's sentence. --When the luckless hour arrived for this barbarity to be inflicted, mothers scratched their faces in grief as their babes, less than three years old, were taken from their arms. Honored elders

\footnotetext{
${ }^{61}$ Dagmar Schaeffer, Portuguese Exploration to the West and the Formation of Brazil, 1450-1800, (Catalogue of an Exhibition. John Carter Brown Library, 1988), 17.

${ }^{62}$ Robert Garfield, A Forgotten Fragment of the Diaspora: The Jews of São Tomé Island, 1492-1654." The Expulsion of the Jews-1492 and after, (Garland Publication New York) 73.

${ }^{63}$ Garfield, A forgotten Fragment,73.
} 
tore their beards when the fruit of their bodies was snatched, before their eyes. The fated children raised their piercing cries to heaven as they were mercilessly torn from their beloved parents-Several women threw themselves at the king's feet, begging for permission to accompany their children, but not even this moved the king's pity. One mother, distraught by this horrible unexplained cruelty, lifted her baby in her arms, and paying no heed to its cries, threw herself from the ship into the heaving sea, and drowned embracing her only child. --Finally, when those innocent children arrived in the wilderness of São Tomé, which was to be their grave, they were thrown ashore and were mercilessly left there. Almost all were swallowed up by the enormous lizards on the island and the remainder, who escaped these reptiles, wasted away from hunger and abandonment. ${ }^{64}$

Similar to Garcia de Resende's narration of the deportation of Jewish Orphans, Malyn Newitt posits that subsequently after the death of King John II of Portugal, his successor and cousin King Manuel deported more Jewish refugees to the island of São Tomé. ${ }^{65}$ Hull adds that Jews and Christians were exiled to Africa for committing minor offenses like petty theft and that they were mainly sent to the Island of São Tomé. The Island had gradually become a hub and a key base for the exportation of slaves to Europe. ${ }^{66}$

The story of the Jews of São Tomé is one that is remembered for the heart-wrenching narrative of children being torn away from their parents. However, this is not mostly the case as has been discussed. The inhabited Island of São Tomé though discovered by the Portuguese in 1470 had served as an escape route for Jews whom willing emigrated to the Island before the Sephardic Orphans debacle in 1492. According to Hull, the Portuguese crown sponsored the settlement of the Island of São Tomé and opened it up for trade purposes between the Niger-delta

\footnotetext{
${ }^{64}$ Samuel Usque, Chronicles, pp. 71-72, from Jane Gerber, The Jews of Spain, 141

${ }^{65}$ Richard Hull, Jews, and Judaism in African History, (Markus Wiener Publishers, Princeton, 2009). 93.

${ }^{66}$ Ibid, 93.
} 
and southwards. The Island soon served as a base for slave trade which the Portuguese had already dabbled into in the 1480 s, capturing slaves from the area known today as Nigeria. ${ }^{67}$

\section{Tracing the Lineage of the Sephardic Children of São Tomé}

Different scholars have attempted to account for the fate of these children. However, they have come up with different historical analogies. As has been identified, some narratives conclude that wild animals devoured these children, while some insist that they were sent to foster families or monasteries for religious training and education. ${ }^{68}$ Simmons, however, argues that there is no evidence to back up the fate and psychological state of these orphans. According to him, we cannot "understand the extremes of guilt and rage undergone by the children in their first years after capture and conversion.

Simms argues, "We need to call on contexts and analogies" in line with similar events, which occurred during the 1400 s to enable us to reconstruct the experiences of these kids. ${ }^{69} \mathrm{He}$ firmly jettisons the ideas and legends that lizards consumed these Sephardic Orphans as rumors and further dismisses them as the figment of the imaginations of chroniclers and eulogizers. ${ }^{70}$

On this note, Hull maintains that the children were nearly two thousand in number and were trained to become farmers. However, only about six hundred survived. These survivors played a vital role in the São Tomé planters' community. ${ }^{71}$ Some eventually became wealthy and

\footnotetext{
${ }^{67}$ Ibid, 90.

${ }^{68}$ Norman Simmons, Devoured by wild animals, (Delhi: Sharada Publishing House), 163.

${ }^{69} \mathrm{Ibid}, 169$.

${ }^{70}$ Ibid, 179.

${ }^{71}$ Hull, Jews, and Judaism in African History, 90.
} 
influential on the island, although still bore the designation of descendants of Jews or new Christians. ${ }^{72}$ According to Norman Simmons, this newly discovered island had proved difficult to settle because of the extreme, "disease-ridden climate." Simmons alludes that this harsh weather and the events that led to the departure of the Sephardic children from Portugal alongside the tumultuous condition of the sea led to the death of almost three-quarters of these children. ${ }^{73}$

Some Scholars also posit that these Orphans were eventually married off to Africans by design and that by 1510 a mixed population of mestizos had emerged, whose descendants became rich and powerful. Norman Simms posits that this mestizo population was notorious for "obstreperousness and cruelty," an attitude most likely inherited from their parents due to internalized anger and fears. ${ }^{74}$ Some of who laid the foundation of the Trans -Atlantic Slave trade and modern plantation system of agriculture. ${ }^{75}$ According to a report to the King in 1529 , a plantation owner Joao Lobato complained that, the "New Christians" had become very influential, owning the best lands and that they used "force with impunity" in administering their affairs in São Tomé. ${ }^{76}$ Echoes of religious intolerance, which manifested in the Iberian Peninsula was carried over to São Tomé.

\footnotetext{
${ }^{72}$ Garfield, A Forgotten Fragment, 75.

${ }^{73}$ Simms, Devoured by wild animals, 163,164 .

${ }^{74}$ Norman Simms, Jewish Children of São Tomé,(2003) http://simmsdownunder.blogspot.com/2013/05/jewishchildren-of-São Tomé.html. Accessed 10/01/2019.

${ }^{75}$ Hull, Jews, and Judaism in African History, 91.

${ }^{76}$ Garfield, A forgotten Fragment, 76.
} 
Evidence of religious intolerance can be traced to the use of the term New Christians in some documents addressed to the King of Portugal in the late 1500s and early 1600s. The issue of appointing New Christians to occupy certain political offices on the Island point to this kind of discrimination. Notably, in 1556, one Bishop Cao removed an occupant of an office, due to his 'New Christian' status. ${ }^{77}$ It is understood that this was the term used for the Sephardic conversos in Spain and Portugal.

Also in 1597 after the death of the Governor of São Tomé, Vasco de Carvalho, it was reported that Joao Barbosa de Cunha, a wealth New Christian was chosen as interim Governor. Barbosa appealed to the King of Portugal for ratification of his appointment by the people. In his note to the King, he alluded to his heritage as an encumbrance, hence his appeal for ratification, which was granted by the King. Religious orientation and heritage was an important factor on the Island. ${ }^{78}$

According to Garfield, color did not mean much on the Island, as religious purity was more important to the Portuguese officials. However, in 1623 Governor Melo Fernando informed the King of the apparent scarcity of "white people" on the Island. A situation, which he must have considered a problem. Garfield noted that "the virtual lack of whites on the Island might suggest that 'Jews" by whatever definition could hardly be found there either, "pointing out that Blacks had become 'New Christians' who practiced Judaism. ${ }^{79}$ However, this assertion by

\footnotetext{
${ }^{77}$ Garfield, A forgotten Fragment, 77.

${ }^{78}$ Ibid, 77.

${ }^{79}$ Ibid, 78.
} 
Garfield is unsubstantiated, as he provided no document or source to conclude that the term 'New Christians' were no longer designated to Sephardic Jews.

In the early 1700s, the Catholic Church in São Tomé was concerned about the spread of Judaism, to the extent that the clergy was ordered to suppress it. According to Garfield, the revival of charges of the practice of Judaism was largely politically motivated. For him, this was a ploy to discredit the opposition. ${ }^{80}$ The problem of Judaism did not seem to go away, as other documents reveal that the church made continuous effort to exterminate the religion from the Island. Garfield maintains that this had become an obsession and concluded that Judaism was nonexistent in the Island, at least at the time of these accusations. He insists that the accusations of 'Jewishness" were merely a political scheme, which had its roots in Iberia ${ }^{81} \mathrm{He}$ also attributes the absence of the "white Jewry" to capital flight, when Brazil's sugar production eclipsed that of São Tomé. Concluding that many Jews who formed part of the middle and upper class in São Tomé migrated to Brazil. ${ }^{82}$

Norman Simms also supports the Brazil migration of the descendants of the Sephardic Orphans. They were re-christened 'mestizos', a term many scholars believe was due to their Jewish origin. Some state that it was because they were of mixed race. According to Simms, the mestizo elites seem to have migrated from São Tomé in the late 1600s, at a time where it was recorded that Jews were spoken of in Brazil. Although his conclusion relies heavily on speculation rather than facts, he argues that the decision to make this move was due to the

\footnotetext{
${ }^{80}$ Garfield, A forgotten Fragment, 78.

${ }^{81}$ Robert Garfield, Public Christians, Secret Jews: Religion and Political Conflict on São Tomé Island in the sixteenth and seventeenth centuries, (The Sixteenth-century journal, 1990), 654.

${ }^{82}$ Ibid, 649.
} 
political and economic instability of the São Tomé Island. ${ }^{83}$ Simms concludes that a large portion of the history of these Sephardic Orphans was lost, even though it was speculated that they resurfaced in Brazil.

Garfield argues that the Portuguese easily described religious practices they did not understand including African religions as evidence of Judaism, hence the renewed designation of Blacks as New Christians. He concludes that much as the "Lost Tribes" acculturated with other dominant cultures and that the Jews of São Tomé followed suit in this pattern. ${ }^{84} \mathrm{He}$, however, fails to provide any source or evidence for this argument. In another work, Garfield argues that São Toméans including the Sephardic Jews and the Africans "forgot their varied origins or the mode of their arrival on the Island." He posits that the Jews and the Africans blended racially and culturally until only the São Toméans remained, who were brown in complexion. ${ }^{85}$

On the contrary, Libi Astaire writes differently concerning the Sephardic Jews forgetting their origin. He points out that the prejudices of the suspicion of Conversos secretly practicing Judaism followed them from Europe to São Tomé. Also, he points out a 1632 document, which states "the island (São Tomé) is so infested with New Christians that they practice the Jewish rites almost openly." 86 Thereby depicting a close connection between New Christians and Jews, referring to both as the same.

\footnotetext{
${ }^{83}$ Simms, Jewish Children of São Tomé, (http://simmsdownunder.blogspot.com/2013/05/jewish-children-of-São Tomé.html.) Accessed 10/01/2019.

${ }^{84}$ Garfield, A forgotten Fragment, 82-84

${ }^{85}$ Garfield, Public Christians, secret Jews, 647

${ }^{86}$ Cuvelier, Jean. L'ancien Congo d'après les archives romaines, 1518-1640. Vol. 36. J. Duculot, 1954.
} 
On a recent trip to São Tomé, Professor Liba Moshe a former Israeli Ambassador to São Tomé accounted for a significant number of São Toméans who are "light-skinned," alluding to their Jewish heritage. Astaire however quickly pointed out that there is a possibility that they are just descendants of the other Portuguese criminals who were also sent to the Island. ${ }^{87}$ To either prove or disprove the contemporary presence of remnants of Sephardic Jews on the São Tomé Island, a study was carried out to "elucidate the genetic impact of the historical Jewish migration to São Tomé." According to the study, several documents account for miscegenation on the island as well as the movement of other New Christians to São Tomé from the Iberian Peninsulas.

The study concluded in respect of the samples taken, that most of the DNA haplogroups which were detected are $95 \%$ of African origin, and that only a single sample which was taken belongs to the European haplogroup. The study also revealed that the Putative Jewish haplogroups $\mathrm{J}$ and $\mathrm{T}$ were also not detected among the samples garnered. According to the scientists who carried out this study:

In the present study, using a large set of both recombining and non-recombining markers, no significant differences were detected between the alleged Jewish descendants and the host population, showing that no particular database is required in forensic cases in relation to Jewish ancestry, contrasting with previous findings on population heterogeneity when other ethnic criteria were considered. ${ }^{88}$

\footnotetext{
${ }^{87}$ Liba Astaire, Sighs, Sugar and Slaves; what happened to the Jewish Children of São Tomé, (libastaire.weekly.com).

${ }^{88}$ Nogueiro, Inês, CéliaNeto, Sofia L. Marques, Cíntia Alves, Nicole Cohen-Addad, AntónioAmorim, Leonor Gusmão, and Luis Alvarez. 2015. "Exploring Sephardic Lineages in São Tomé E Príncipe." Forensic Science International: Genetics Supplement Series 5: e461.
} 
The study found no traces of Sephardic Jewish DNA amongst the samples they collected. Besides, the scientific data may support scholars who have traced the movement of the descendants of the Sephardic Jews of São Tomé to Brazil, or at best that they must have at one point left São Tomé completely. It is unlikely that Jews who lived on the island for years will not have any genetic trace to the area. Notwithstanding, one thing is evident; there abound different narrations and possibilities regarding the history and contemporary location of the Sephardic Orphans. It is also evident that there is a lacuna in their story. This gap, which is yet to be filled with historical evidence, has opened up this story to a floodgate of speculative analogies and curious appropriations. This includes the speculation that this event was one of the inroads to the presence of Judaic related practices in sub-Saharan Africa.

This chapter attempted to account for the Sephardi Jewish Children of Sao-Tome, by tracing their movement from Spain through Portugal and then Sao-Tome. It also considered the perspectives and speculations of other Scholars and scientists regarding the story of these children, and the quest to trace their lineage and geographical trajectory. However, this chapter identified that there lies an obvious lacuna in their story and attempted to account for this reason.

The lacuna in the story of these Sephardic orphans and their descendants who have become scarce still persists. Despite scientific findings, it may be attributed to the fact that issues regarding race, unfortunately, breeds unnecessary tension. Although documents clearly show that New Christians were still living on the island into the 1800s, it was discussed that some scholars had dismissed the use of the term New Christians for conversos alone. It was also discussed that no evidenced was adduced to buttress the sudden change in designation of the conversos to include African São Toméans and Moors. This has made the task of historically tracing the 
whereabouts of the descendants of the Sephardic children, a herculean task. Nonetheless, the story of the Jewish children of São Tomé is incomplete. It remains in the annals of mystery, which has opened it up for a myriad of appropriations and reconstructions, often considered as one of those tales from Africa. 


\section{DISCUSSION}

\section{Judaism from Africa to the world}

This section discusses the development of Judaism within the African context. It traces the emergence of what is now considered Black Judaism or African Judaism. The crisscrossing of Judaic ideas across the Atlantic to the Americas is also identified, as well as the crisscrossing of African Americans to parts of Africa, which were considered bastions of African Jewish heritage. Particularly how these idealistic strong holds of Jewish heritage in Africa played a significant role in the emergence of Jewish movements in the United States. The various TransAtlantic conversations of Jewish identity, which led to the various appropriation of portions of Jewish history, which includes the story of the Sephardic Jewish Orphans is also considered in this section.

The conversations about African Judaism or the idea of Black Jewish connections has become a phenomenon that generates so much interest in not only religious circles but also the academia. People are continually fascinated by the practice of Judaism by Blacks. The buzz of this fascination is not merely based upon the ability of blacks to practice Judaism since the religion clearly has provisions for the conversion of non-Jewish people. However, interests are spurred due to the claims made by a significant portion of black practicing Jews in not only Africa but also the United States. These claims, which have metamorphosed from echoes to the formation of mass movements all around the world, are hinged upon the idea that originally Jews are Blacks. 
Many scholars have attempted to answer the difficult question of how "African Jews and Africans claiming Jewish and/or Israelite heritage-how they came to be in Africa. ${ }^{89}$ A continent detached in no small extent from the Middle East, where the land of Israel is located. Others have focused on the issue of race and the color of the Jews while tracing the history of the identification of Jews as either Blacks or whites. ${ }^{90}$ Despite these noble attempts, the phenomenon of Black Judaism persists and arguably takes on a new dimension each passing day.

Various forms of Judaism and Jewish practices and rituals can be recognized all over the 'Black world.' Tudor Parfitt describes the many groups associating themselves in one way or the other to be "emerging Jewish communities."91 Scholars have therefore made attempts to investigate the various Jewish practices by these emerging Jewish communities. Some have even taken significant steps at genetically linking a portion of these black groups and communities to the Jews. Notably is the Lemba tribe of South Africa, whose traditions did not only resonate with Judaic rituals but their DNA as well. ${ }^{92}$ Upon his visit to the Lemba tribe, Parfitt identified various rituals Jewish rituals and practices, which he believed to Semitic Middle Eastern and not particularly an African practice. ${ }^{93}$

The idea of Black Judaism and the narrative of Jews being Black is not recent. It is complex and can be historically traced to the medieval period. Some Scholars had even

\footnotetext{
${ }^{89}$ Marla Brettschneider,The Jewish Phenomenon in Sub-Saharan Africa, (Lewisten, Edwin Mellen Press, 2015) 131.

${ }^{90}$ Parfitt, Black Jews in Africa and the Americas, 1, 12.

${ }^{91}$ Parfitt and Fisher. Becoming Jewish: New Jews 3.

${ }^{92}$ Thomas, Mark G., Tudor Parfitt, Deborah A. Weiss, Karl Skorecki, James F. Wilson, Magdel Le Roux, Neil Bradman, and David B. Goldstein. "Y chromosomes traveling south: the Cohen modal haplotype and the origins of the Lemba - the "Black Jews of Southern Africa." The American Journal of Human Genetics 66, no. 2 (2000): 674686.

${ }^{93}$ Tudor Parfitt' Remarkable Quest, NOVA, PBS, 22 February 2000
} 
attempted to trace the development of African and Jewish interaction and identity in Africa to Biblical times when the children of Israel were domiciled in Egypt. According to Richard Hull, "Egypt's influence on these Semitic-speaking peoples of the Middle East was undoubtedly quite strong — during their sojourn in Egypt they developed unique rituals and dietary restrictions", and to a large extent, it is speculated that the Jews also developed a monotheistic based system of worship introduced by Pharaoh Akhenaten.

Although unlike the Israelites, indigenous Africans still maintained the idea of lesser deities imbibing some sort of authority, however subject to the Supreme God. Other forms of religious traditions such as the taboo of depicting the Supreme God in any physical form, is also speculated to have significantly influenced ancient Israelites. ${ }^{94}$ Whichever narrative is strictly adhered to, it is evident, that Blacks and Jews have in no small measure a complex history, which has been built upon and served as a base for the creation of not only distinct religious identities but also a dynamic relationship.

The emergence of multiple forms of Judaism, particularly the idea of African Judaic practices, can be attributed to varying reasons and factors. Firstly, the myth of the 'Lost tribes of Israel', the allegorical associations of the shared experiences of suffering, discrimination, and slavery of Blacks and Jews alike, the Hamitic theory, associating some Africans as the descendants of Ham, colonial conspiracies and manipulations and finally the presence of similarities in the culture and traditions of indigenous Africans and Jewish practices and rituals.

It is noteworthy that many Africans and African Americans genuinely practice Judaism by way of conversion and other convictions. Although often times their conversion is strictly based on spiritual convictions. However, there exist factors distinct from genuine spiritual

\footnotetext{
${ }^{94}$ Hull, Jews, and Judaism in African History, 5,6.
} 
conviction, which are the underlying motivations for the emergence of Black Judaism in Africa, the United States of America and some other parts of the world, at least within the fringe of its origins.

\section{Colonial Conspiracy and the Justifications for Slavery}

Various schemes and vices characterized the advent of colonialism and the TransAtlantic slavery. The Europeans in their bid to not only gain psychological access to the colonized but also to sell alternative justifications for slavery imposed Jewish identities across Africa. European incursion into Africa, therefore, gave rise to the myth of the Lost Tribes of Israel as well as the Hamitic concept, which served its function by portraying the Negro as an inherently inferior being. Thus the justification of trading black slaves. ${ }^{95}$

On the one hand, the Lost Tribes ideas was a product of Biblical interpretations regarding the twelves sons of Jacob. Their descendants, who occupied the land of Israel, were subsequently split into two kingdoms. This includes the Northern Kingdom or the Kingdom of Israel, which consisted of the ten tribes, and one Southern Kingdom, which consisted of the members of three tribes. The ten tribes were then scattered abroad upon captivity, from which it is believed that they dispersed into other parts of the world, hence the first wave of Jewish diaspora. ${ }^{96}$

On the other hand, the Hamitic theory was based upon a biblical narrative, where Canaan, the first son of Ham received a curse from Noah due to a sin Ham committed. The association of Ham with Africans was therefore re-appropriated by the some scientists and the colonists for the

\footnotetext{
${ }^{95}$ Sanders, Edith R. "The Hamitic hyopthesis; its origin and functions in time perspecive." The Journal of African History10, no. 4 (1969): 521-532.

${ }^{96}$ Parfitt, Black Jews in Africa,.13,14
} 
sole purpose of dominating Africans. ${ }^{97}$ Although the Hamitic theory has under gone various interpretations and scholarly investigations, it held sway and garnered traction from the Napoleon's invasion into Egypt in 1798, through the Middle Ages, even up to the $19^{\text {th }}$ and $20^{\text {th }}$ centuries. ${ }^{98}$ This resulted in the continuous perception of Africans, particularly Non-Egyptians and Ethiopians to be seen as inferior. This narrative of accursed Canaan being the biblical ancestor of Africa and the black race, held sway and was uncontested until the end of the Renaissance period. A new interpretation of the Hamitic theory was however put into use, arguing that everything considered historically valuable were originally created by Africans of Hamitic descent, and not by Africans who were the descendants of Canaan, who were not part of the progressive Hamite stock, such as the Egyptians. In essence, there was an attempt to distinguish Egyptian and Ethiopian Africans from the rest of Africa, due to the obvious historical civilization of Egypt and Ethiopia. ${ }^{99}$

Some scholars argue that the idea of Black Jewish identity was a product of colonial conspiracy and that racial identities were suggested and imposed in many places where the colonial situation was introduced. ${ }^{100}$ According to Parfitt:

The creation, suggestions, or imposition of identities. Narratives and histories by colonists, missionaries, and others were but one aspect of a complex interaction between colonizer and colonized, between Europe and Africa - in which the trope of Israelite origins for a multitude of peoples, as a global phenomenon, formed an integral part. ${ }^{101}$

\footnotetext{
${ }^{97}$ Parfitt, Black Jews in Africa Ibid, 24.

${ }^{98}$ Edith Sanders "The Hamitic hypothesis, The Journal of African History10, no. 4 (1969): 534.

${ }^{99}$ Sanders "The Hamitic hypothesis, 532.

${ }^{100}$ Parfitt, Black Jews in Africa, 10.

${ }^{101}$ Ibid, 103.
} 
A notable example is the creation of the Igbo-Jewish identity in Nigeria, West Africa. The Igbo ethnic group, are a group among many other African groups claiming a Jewish identity. Many African Americans constantly allude and refer to their African Jewish origins to emanate from the various Black Jewish groups scattered across Africa. This includes the Igbo ethnic group of present-day Nigeria. ${ }^{102}$

The Igbo Jewish identity is merely a drop in the ocean of Jewish impositions and claims of Jewish identity all across Africa. Similarly, the colonists imposed Jewish hybrid identities in other parts of Africa. These Jewish ideas were not only spread during the colonial era but have been sustained in various parts of Africa. The creation of these Jewish identities has more to do with the advent of colonialism and the Trans-Atlantic Slave trade than it has to do with genuine Jewish conversion or genealogical affinity. According to Edith Bruder, "The modern Judaizing movements are often linked more to unexpected reactions to colonialism than to the implantation in Africa of Jewish ideas, practices or people, at some remote time." ${ }^{103}$ In addition, Parfitt states that "in Africa, as in America, the acceptance, adoption, or internalization of an Israelite religious or ethnic identity was often a means of using a colonial discourse for some useful and dignified spiritual end." 104

Some scholars refer this colonial mindset and practice as Christian millennialism, which was hinged upon the conversion of the Jews to Christianity and their subsequent restoration to the holy land as a pre-condition for the second coming of Christ. ${ }^{105}$ According to Lis, there are

\footnotetext{
102 Parfitt, Black Jews in Africa and the Americas, 99.

${ }^{103}$ Bruder, The Black Jews of Africa, (2008). 133-134

${ }^{104}$ Parfitt, Black Jews in Africa and the America, 103

${ }^{105}$ Daniel Lis, Ethiopia shall soon stretch out her hands': Ethiopian Jewry and Igbo Identity, (London, Taylor and Francis, 2009): 22-23
} 
early descriptions of Ethiopian Jews and Igbos along the same culture pattern, which were christened, Jewish. Incidentally, this was done around the same time, which may not just be a coincidence. Strong belief in this apocalyptic prerequisite, spurred the Lost Tribe theories, which saw to the British colonists speculating about the Lost tribes' remnants in Africa. The identification of Jewish practices among the Igbo and the recognition of Ethiopians as Jews by the British were products of this millennialism mindset.

As mentioned earlier, some African Americans draw the inspiration of Jewish identity from the Igbo who are geographically located in the Bight of Biafra, around the coast of West Africa and the Ethiopian Jewry. The Igbo Jewish identity is a phenomenon that can be traced to specific colonist related historical and textual resources, which identified various Jewish similarities among Igbo cultural practices and cosmology during the colonial era. Prominent on this list are the works of Christian Georg Andreas Oldendorp, a Monrovian missionary who provided the first ethnographic resource about the Igbo in his report titled "Geschichte der Mission der evangelischen Brüder auf den caraibischen Inseln S. Thomas, S. Croix und S. Jan," which was published in 1777.

Oldendorp pinpointed certain distinct Jewish cultural practices similar to the enslaved Africans of Igbo extraction. Notably, he recognized male circumcision rites, in which he noted that the Ibo do not allow an uncircumcised slave among them. He states that they only consider him an equal human being after circumcision. ${ }^{106} \mathrm{He}$ also identified various purification rites by women, sacrificial rituals, and consecration of a sub-group of people to serve as priests. He identified Levitical paradigms in the Igbo culture, and he wrote that, "Amongst the Ibo, they (the priests) are chosen from a group of people they call living sacrifices. They live celibate, without

\footnotetext{
${ }^{106}$ Daniel Lis, Jewish Identity Among the Igbo of Nigeria, 13.
} 
property and at the expenses of others, and they have the liberty to take everything they need from others, all of what they need and nobody stops them." 107

Subsequently, other writers wrote on the Igbo, which significantly influenced Igbo worldview and perspective. Worthy of note, are the works of George Thomas Basden titled "Among the Ibos of Nigeria: An account of the curious \& interesting habits, customs, \& beliefs of a little known African people by one who has for many years lived amongst them on close \& intimate terms." in 1921. He also wrote "Niger Ibos: a description of the primitive life, customs, and animistic beliefs, \&c., of the Ibo people of Nigeria by one who, for thirty-five years, enjoyed the privilege of their intimate confidence and friendship," first published in 1938. Like Equiano and Oldendorp before him, he identified strong Jewish cultural traits amongst the Igbos. Having lived in Igboland for thirty-five years, he also identified in his monographs, certain Jewish similarities. He wrote; "To any contemplating residence in the Ibo country, particularly those likely to be associated with native affairs, I would recommend a careful study of Levitical Law. In many ways, the affinity between Native Law and the Mosaic System is remarkable." 108

These colonists' inspired works significantly influenced the propagation and establishment of the Igbo-Jewish identity in Nigeria. According to Adiele Afigbo:

For their part, the British colonizers had their reasons for promoting the idea that certain Igbo peoples had been influenced by 'civilized' Middle Eastern societies like the Hebrew or Egyptian-- this theory helped the British establish a typology through which they could administer the notoriously decentralized Igbo areas directly. ${ }^{109}$

\footnotetext{
${ }^{107}$ Lis, Jewish Identity Among the Igbo of Nigeria, 14.

108 George Basden, Niger Ibos, (London, Frank Cass, 1966), 411.

${ }^{109}$ Eberechukwu Afigbo, Nigerian history, politics, and affairs: the collected essays of Adiele Afigbo., (New Jersey, Africa World Press, 2005) 9.
} 
Other scholars posit that apart from the underlying colonists' intent for using the Lost Tribes of Israel narrative in some parts of Africa, they also peddled this narrative as a part of a "millennial fervor" to identify and gather these Lost Tribes for speeding up the coming of the Messiah. ${ }^{110}$ The success of these ideas as seeds that germinated quite rapidly can be seen in works of other Africans writers like Olaudah Equiano whose autobiography was first published in 1789 in London. It was titled "The Interesting Narrative of the Life of Olaudah Equiano." He was a freed African Slave, and his book served as a significant source of information on the Igbo, both for Igbos and non-Igbos alike. ${ }^{111}$ Equiano identified his origin and place of birth in 1745 in Essaka. Equiano identified his origin and place of birth as Essaka, and the year to be 1745 . Some Scholars have identified same to be present day Isseke, in Anambra State Nigeria. ${ }^{112}$ Equiano's auto-biography was similar to Oldendorp's ethnographic work. Like Oldendorp, Equiano identified multiple Jewish traditions identical to that of the Igbo. In recollecting his childhood days in Africa, before his enslavement, Equiano wrote that:

We practiced circumcision like the Jews, and made offerings of feasts on that occasion in the same manner as they did--If my recollection does not fail me, like the Jews, Those that touched the dead at any time were obliged to wash and purify themselves before they could enter a dwelling house--And here I cannot forbear suggesting what has long struck me very forcibly, namely, the strong analogy which even by this sketch, imperfect as it is, appears to prevail in the manners and customs of my countrymen and those of the Jews, before they reached the land of promise, and particularly the patriarchs while they were yet in that pastoral state which is described in Genesis. ${ }^{113}$

\footnotetext{
${ }^{110}$ Doman, Chosen People, 57

${ }^{111}$ Ibid, 17.

${ }^{112}$ Chima Korieh, The Nigeria-Biafra War, Genocide and the Politics of Memory, (New York: Cambria Press, 2012), 2.

${ }^{113}$ Olaudah Equiano, The interesting narrative of the life of Olaudah Equiano., (Ontario, Broadview Press, 2001.), 30-32.
} 
Equiano identified multiple cultural traits of the Igbo, which he considered strikingly similar to that of the Jews. These similarities ranged from administration to monotheism, circumcision, purification, and even priestly hereditary laws. Although the idea of a link between the Jews and Africans was not peculiar to Equiano's narrative because he often cited copious contemporary biblical scholars who aligned with this narrative. ${ }^{114}$

The link between Africans of West African descent and not the typical Ethiopic connection appeared to be peculiar to Equiano's narrative. Some scholars posit that the image of the Igbo alongside a presumed Jewish identity and heritage was influenced mainly by Equiano's autobiography. ${ }^{115}$ Parfitt adds, "Equiano's ideas won the wide acceptance by the black Jews in the United States and in Nigeria." 116

Many other writings about the Igbos and other supposed African Jews abound. Writers such as Africanus Horton, also known as James Beale wrote on the Igbo, which significantly influenced Igbo worldview and perspective regarding their affinity to the Jews of ancient Israel. ${ }^{117}$ Many Igbos and by extension African Americans drew their inspiration and got to know about their culture and Jewish ancestry through the eyes of writers such as Oldendorp, Equiano, Horton,Basden, and Charles Kingsley Meek, who were primarily influenced by the colonists.

\footnotetext{
${ }^{114}$ James Walvin, An African's life: the life and times of Olaudah Equiano, 1745-1797, (London, Weidenfeld\& Nicolson, 1998),8.

${ }^{115}$ Lis, Jewish Identity among the Igbo of Nigeria, 25.

${ }^{116}$ Parfitt, Black Jews in Africa and the Americas, 106

${ }^{117}$ Ibid, 111.
} 


\section{Counter Theology as a form of Resistance}

Some Scholars do not particularly align with the idea that Black Judaism emerged out of encounters of blacks with Jews. They contend with the idea that the supposed Jewish identity of black slaves was a result of the influence of Jewish slave masters or any colonial conspiracy or manipulation. According to James Landing, Black Judaism emerged from the need for social protest, a sort of resistance mechanism applied by the Blacks to fight back against social injustice, ill-treatment, and frustration against discriminatory laws against the blacks such as the Jim Crow laws. He posits that the independence of the Black Churches played a significant role in the development of Black Judaism. ${ }^{118}$ He argues that the early conversion of Blacks to Judaism has nothing to do with the emergence of Black Judaism.

It is important to note that Landing's argument does not entirely dismiss the idea of some conspiracy by the colonizers and Slave masters; it, however, reveals a different layer of the latency of the colonial conspiracy discussed earlier. Christianity in the form of independent black churches was the meeting point for Black Jewish encounters. According to Yvonne Chireau upon the consideration of recurring themes and perceived shared experiences, which includes the common history of dispersion, slavery, and emancipation between the blacks and Jews, Judaism contributed significantly to shaping the character of African American life. For her, the product of these encounters was the creation of various adaptations and appropriations of Judaism within Black Judaism. "African Americans gave meaning to their ordeal of slavery by highlighting the correspondences between their own experiences and those of the biblical Jews." 119

\footnotetext{
${ }^{118}$ James Landing, Black Judaism: story of an American movement, (Durham, CAP, 2002), 13.

${ }^{119}$ Yvonne Chireau, Black Zion, (Oxford University Press, 1999), 16-17
} 
The inventive approach in which African Americans adapted and appropriated portions of the Old Testament of the Hebrew Bible was unique. The exposure of the black population in the United States to the stories of the Bible gave rise to the adoption of a new revered, figurative, and subsequently imagined world created by the black people based on the Bible. This occurred in an attempt to provide a psychological haven from the discrimination they face globally. Apparently, the details of the Hamitic hypothesis, which described black Africans, particularly Africans dwelling, south of the Sahara, as inferior, and the peddling of racial justifications for slavery had gotten to the black population. They, therefore, attempted to use the same stories that were used to subjugate and enslave them as a means of defending themselves. ${ }^{120}$

As discussed earlier, Black Jewish encounters were facilitated by Christian gatherings and the use of the Hebrew Bible in these gatherings. Nonetheless, Muslim slaves who came from some African countries already influenced by Islam also transmitted some of these biblical stories, however in line with their knowledge of the Koranic versions. ${ }^{121}$ Biblical Stories of Moses and his bold confrontation of Pharaoh, the oppressed Hebrews slaves and their subsequent exodus to the land of Canaan resonated significantly with the black population. ${ }^{122}$ These biblical narratives, therefore, made the black population to perceive their dehumanizing experiences in the hands of their slave masters in a redemptive light and considered their status through the lenses of the memory of their African traditions.

\footnotetext{
${ }^{120}$ Parfitt, Black Jews in Africa and the AMericas, 74

${ }^{121}$ Ibid, 75.

${ }^{122}$ Chireau, Black Zion, 18,19
} 


\section{African and African-American Judaism: Two peas in one pod}

It is noteworthy, that just like in Africa Jewish identity influenced Africans across the divide. However, it was not just a one-way movement from Africa. This is evident in the case of the Igbo where Equiano's narrative significantly influenced the Igbo-Jewish identity. It can, therefore be said that the African Jewish idea flowed in both directions. ${ }^{123}$ Particularly, in the Americas, Black Jewish identity was gradually becoming gospel for African Americans. Many other writers graciously supplied the material for the propagation of these ideas. Israelite racial identities were therefore accepted and internalized. Consequently, these hybrid religious ideas were spreading like brush fire in Africa and among the black population in the United States.

The African Jewish narrative was sustained by various travel and missionary literature concretizing the belief of the presence of Black Jews in Africa. Notable among the works which the African American population drew inspiration from includes Equiano's autobiography published in 1789, and Charles Pennington's "A Text Book of the Origin and History of the Colored People." Other authors included Africanus Horton, an educated African of Igbo origins, whose book became popular among major African American intellectuals' and writers. According to Parfitt, "between this efflorescence of Jewish activity and identification in Igboland and the Black Jewish movements of the United States and elsewhere in Africa, there is a good idea of connection, symbiosis, and communication." 124

The symbiosis and connection of Igbo Jewish identification and the emergence of Black Jewish movements in the United States are often downplayed. However, there are possible clues

\footnotetext{
${ }^{123}$ Dorman, Chosen People, 3.

${ }^{124}$ Parfitt, Black Jews, 112.
} 
to this connection. As has been mentioned earlier, some writers whose works influenced Black Jewish movements in the 1800's such as Equiano and Horton were of Igbo ancestry. More so, at the peak of the Trans-Atlantic Slavery, Igbo dominated areas became one of the locations in West Africa most affected by the transatlantic slave trade. ${ }^{125}$ According to J.N Orji, the Igbo were among the leading exporters of slaves to Europe and the Americas from the $17^{\text {th }}$ to the $19^{\text {th }}$ century. ${ }^{126}$ This accounts for spasms of Igbo culture and religious practices which can be identified amongst various descendants of victims of the trans-Atlantic slavery.

Some scholars have accounted for the export of Igbos in large numbers to variant slave colonies in the Americas, including Virginia, Sierra Leone, Jamaica, Trinidad, and Maryland. A good example will be the unofficial designation of colonial Virginia as 'Igboland. ${ }^{127}$ It is therefore put forward that due to the concentration of enslaved Igbo in these colonies, the Igbo were consequently distinguished from other African slaves. For some, the yellow skin was highlighted as a significant physical characteristic of the Igbo, and for others, the enslaved Igbo were notorious for rebellious traits and high suicide tendencies, all in their revolt against slavery. ${ }^{128}$

Olaudah Equiano identified this quest for Igbo slaves, which accounts for the high percentage in the various slave colonies. He noted that "The West India planters prefer the slaves of Benin or Eboe, to those of any other part of Guinea, for their hardiness, intelligence, integrity,

\footnotetext{
125 Lis, Jewish Identity, 13.
}

${ }^{126}$ John Orji, Traditions of Igbo origin: a study of pre-colonial population movements in Africa, (New York, Peter Lang Pub Inc, 1994).

127. Ira Berlin, African immigration to colonial America, (The Gilder Lehrman Institute of American History., 2005), paragraph 11

128 Lis, Jewish Identity, 13. 
and zeal. Those benefits are felt by us in the general healthiness of the people and in their vigor and activity." 129 On the other hand, in some cases, they were considered of higher value for subservient reasons. According to Collin Palmer, "The Ibo--were considered tractable and hence were highly sought after by some of the slaveholders in the Americas." 130 The point, therefore, is that in one way or the other, it was easier for most of the black population to identify with the Igbo-Jewish identity from Africa.

The African Jewish connection, which served as a significant catalyst for the emergence of the Black Jewish movement, was not limited to the Igbo Jewish identity alone but the whole of Africa. According to Rabbi Ford, "The motherland Africa is still today the home of millions of these descendants of ancient Jerusalem, and West Africa whence our forebears came may yet be proud that in native customs and traditions she can boast of not being only Semitic but Mosaic"131

The idea that Ethiopians were Jews as well as Ethiopic connections to the Bible also played a significant role. Biblical texts such as "Princes shall come out of Egypt, Ethiopia shall soon stretch out her hands unto God" in Psalms 68:31 was graciously spurred the zeal of the Black churches and Black Jewish movements at their inception. The Ethiopian resistance against colonialism in the battle of Adwa in 1896 also bolstered the Jewish energies of the black population in America, particularly the black churches. Ethiopia therefore symbolically became

\footnotetext{
${ }^{129}$ Arna Bontemps, Great slave narratives, (Boston, Beacon Press, 1969), 10.

${ }^{130}$ ToyinFalola and Raphael Njoku, Igbo in the Atlantic World: African Origins and Diasporic Destinations, (Indiana University Press, 2016), 142.

${ }^{131}$ Jacob Dorman, Chosen People, 190
} 
the Zion in Africa and a sacred symbol for messianic redemption and emancipation for the blacks in the United States. ${ }^{132}$

Many African Americans identified with the Jewish religion, based on their ties to an African Lineage they believe is the source of Judaism. They hinged these claims on the premise that the trans-Atlantic slave trade resulted in the loss of their Jewish heritage. According to Chireau, in the late 1800s, "A variety of embellishments on the theme of African Hebrew origins were advanced within black traditions. ${ }^{133}$ In this case, these Hebraic themes were not imposed by the colonists, but by Africans and African Americans themselves. This pattern persists even today, particularly by members of the Black Hebrew Israelites movement.

There are many other examples and notions of flourishing Ideas of Africans being Jews, however, the Igbo-Jewish identity, the identification of the Falasha of Ethiopia, and in no small extent the Yoruba Jewish connection as Jews, played a more significant role in the emergence and development of various Black Jewish movements in the United States. This is evident in the identification with both Ethiopian and Nigerian ancestry by Rabbi Wentworth Arthur Matthew, one of the founding leaders and great rabbis of the black Hebrew Israelites movement. ${ }^{134}$

These hybrid Jewish ideas from Africa in no small measure shaped the worldview and beliefs of the black community in the United States and subsequently led to the formation of various Black Jewish movements particularly the Black Hebrew Israelites, which turned out to be the most successful project of the Black Jewish community.

\footnotetext{
132 Tudor Parfitt, Black Jews, 83,84

${ }^{133}$ Chireau, Black Zion, 24.

${ }^{134}$ Parfitt, Black Jews, 71.
} 


\section{Black Jews in the United States of America}

By the 1860 's Africans attempted to change the Europeanized Hamitic hypothesis by developing a new racialized understanding of the concept. These writers made attempts to refute if not debunk most of the adverse racial classification of the Black Africans in line with the European hypothesis. These new Afrocentric ideas gave way to a different racialized idea that the presence of black Jews in Africa meant that "blacks were in fact Jews, descended from Jews, and that the central figures in the Judeo-Christian traditions were blacks." ${ }^{135}$ Just before the turn of the twentieth century, these Afrocentric ideas were vigorously developed, which led to the formation of various African American religious groups, such as the Black Hebrew Israelites and other Judeo-Christian congregations under different names.

In 1892, African American preachers, notably Prophet Williams Saunders Crowdy began to preach a message, which appealed to many African Americans at the time. The message was simple; black religion was the true Judaism and blacks literally became Jews. ${ }^{136}$ Although he was not the first to bring this message to the African American community, however, his organization had more impact on Africans in America and some parts of Africa, particularly South Africa. ${ }^{137}$

Ten years earlier Prophet Frank S. Cherry had preached a similar message, claiming that whereas not all blacks were Jews, all true Jews were blacks and that the white Jews were impostors, who originally were descendants of the biblical Gehazi, therefore operating under a curse. ${ }^{138}$ Bishop Christian the founder of Church of the Living God also preached the same

\footnotetext{
${ }^{135}$ Parfitt, Black Jews, 81.

${ }^{136}$ Chireau, Black Zion, 21

${ }^{137}$ Ibid, 21.

${ }^{138}$ Parfitt, Black Jews, 88
} 
message alongside Crowdy during the same period, emphasizing that many Biblical characters including Jesus Christ were of the Black race. ${ }^{139}$

Similar to Cherry's message ten years earlier, Crowdy preached that African Americans did not just become Jews overnight, but that they were descended from the ancient Israelites. ${ }^{140}$ In essence, the history, sacred texts, culture, and experiences of the Jews, wholesomely became theirs, howbeit with moderations in line with their experiences as victims of the Trans-Atlantic Slavery. Crowdy, whom himself was born into slavery in 1847, founded the Church of God and Saints of Christ. His message resonated among the African American community, mainly due to the gruesome era of lynching and the unfortunate rise of the Jim Crow laws, which embodied and enforced racial segregation in the United States. ${ }^{141}$

Crowdy's church and large following crystalized into a movement, which opened the floodgates of Judaizing to the creation of subsequent Black Jewish movements. Examples include, Warren Robertson's Temple of the Gospel of the kingdom, Rabbi Leon Richlieu's Moorish Zionist Temple, and many other Jewish related movements. ${ }^{142}$ Crowdy and his ilk had not only internalized the experiences of ancient Israelites but had begun to relive these experiences in their everyday lives, appropriating whatever discrimination they faced to a biblical moment of the suffering of the Jews. ${ }^{143}$ These ideas spurred the interests of many African Americans and blacks generally in the Americas and led to the formation of various

\footnotetext{
${ }^{139}$ Dorman, Chosen People, 89

${ }^{140}$ Dorman, Chosen People, 3.

${ }^{141}$ Ibid, Chosen People, 7

${ }^{142}$ Parfitt, Black Jews in Africa and the Americas, 91.

${ }^{143}$ Dorman, Chosen People, 23
} 
political and social rights movements. These movements either held unto similar Black Jewish ancestry ideas or re-created their own imagined Jerusalem in either Ethiopia or Africa as a whole. ${ }^{144}$

Worthy of note among the many Black Jewish religious and political movements is the rise of Rabbi Arnold Josiah Ford, who drew upon various ideological sources such as "Judaism, Freemasonry, Garveyism, Theosophy, Christianity, and Islam" in the creation of a black Hebrew congregation called the Beth B'nai Abraham (B.B.A). ${ }^{145}$ Ford insisted that they were not converting to Judaism, rather they had returned to Judaism and that Judaism itself was originally African. He also alluded to West Africa being part of the Semitic world. Ford linked the origins of Black Jews to their contact with Sephardic Jews and claimed that the ancestors of the black Jews suffered the inquisition alongside the ancestors of the Sephardic Jews. ${ }^{146}$

Despite the conflation and discordance of Rabbi Ford's Hebraic ideas and jejune theories, he garnered a large following, which literarily adopted Marcus Garvey's Back to Africa rhetoric. Based on this worldview, which involved the coming together of Africans all around the globe to a national home and promise land, with strong ties to their African past. ${ }^{147}$ In 1930, Ford encouraged some of his followers to emigrate to Ethiopia, an independent African nation with strong ties to ancient Israel and which held a biblical promise "Ethiopia shall soon stretch out her hands unto God." Among his many conflating theories, he held onto this Zionist view and

\footnotetext{
${ }^{144}$ Parfitt, Black Jews in Africa and the Americas, 86.

145 Dorman, Chosen People, 130

${ }^{146}$ Ibid, Chosen People, 190.

${ }^{147}$ Ibid, 134.
} 
preached that African Americans were also descendants of King Solomon through the offspring between him and Queen Sheba of Ethiopia. ${ }^{148}$

Rabbi Ford's dreams of emigrating to Utopian Ethiopia soon met with the harsh reality of a non-existent harmonious relationship between the African American emigrants and the Ethiopians. According to Dorman, "many Ethiopians looked down on African Americans and treated them poorly on account of their slave ancestry and their skin tone." ${ }^{149}$ In a nutshell, Ford's voyage to Africa was a colossal failure. Many of his followers lost faith in him; he soon died of a heart attack in 1935, after Italy invaded Ethiopia.

Despite Ford's ventured Ethiopic failure, his ideas significantly influenced the development of Rastafarianism in Jamaica. ${ }^{150}$ It also projected the idea that the Beta Israel/Falasha of Ethiopia were indeed the ancient Israelites who were stripped of their religious legacy. Although it was on this idea that Rabbi Matthew emigrated to Ethiopia, his emphasis on the Hebraic connection to Israel propagated and made popular the Falasha Israelite idea. ${ }^{151}$

Rabbi Matthew who had acted as Ford's representative in the United States thereupon took over leadership of the Black Israelite movement. From the 1930s to the 1970s, Rabbi Matthew successfully carried on responsibilities as the leader and most prominent figure among the Black Israelites of the African American community. His congregation in Harlem, which he called "Commandment Keepers Church of the living God the Pillar, Ground of Truth, and the Faith of Jesus Christ," was the oldest remaining Israelite synagogue in New York.

\footnotetext{
${ }^{148}$ Chireau, Black Zion, 28

${ }^{149}$ Dorman, Chosen people, 143

${ }^{150}$ Ibid, 148.

${ }^{151}$ Parfitt, Black Jews in Africa and the Americas, 93
} 
It was more or less a coalesced congregation of Rabbi Ford and Rabbi Matthew's congregation. Rabbi Matthew taught and practiced Israelite teachings and believed in the Israelite heritage of Africans and African Americans. However, he introduced certain esoteric scientific modifications. Which included some sort of hybridity with African religions and other mystic religious practices to form a 'polycultural' religion. ${ }^{152}$

Rabbi Matthew subsequently inculcated various Jewish practices, holidays, and rituals among the Black Israelite congregations. This was a clear distinction from the other Black Israelite congregation. Many other congregations had mostly disbanded and were tilted more towards Christianity than Judaism. At a point in Rabbi Matthew's life, he enthused, “I got tired of Christianity, of going from church to church-Got the spirit it wasn't right. Just found this by myself because I wanted Hebrew. Like I was reaching out and discovered this." 153

Matthew's influence on Black Judaism, particularly in the form of its contemporary practices in America and the Caribbean is of immense significance, as he later ordained many black rabbis who subsequently created their own Black Jewish congregations throughout the United States and the Caribbean. ${ }^{154}$ Thereby propagating the message of the Black Hebrew Israelite religion. This was, therefore, the message that guided the practices and belief of the Black Hebrew Israelites. A movement, which has developed all across the United States.

\footnotetext{
152 Dorman, Chosen people, 154-181.

${ }^{153}$ Ibid, 156

${ }^{154}$ Parfitt, Black Jews in Africa and the Americas, 93-94
} 


\section{Who are the Black Hebrew Israelites?}

The Black Hebrew Israelites became active during the $19^{\text {th }}$ century. As discussed earlier it emerged based on the ideology of the Lost Tribes of Israel, which led to the belief that there were black Jews in Africa. In addition, the various biblical analogies based on the shared Jewish experiences by virtue Black Jewish encounters served as a base for its formation. These ideas led to the widespread notion among the black population in the United States that Jews are Black, and have been black right from antiquity, through to the Trans -Atlantic slavery.

Despite the certainty of the period when the organization was created, scholars have not unanimously agreed upon perspectives regarding the motivations for its creation. The ideas, which led to its emergence, was circulated in newspapers, pamphlets, and books from pulpits of African American churches with black audiences throughout the eighteenth and nineteenth centuries. $^{155}$

The Black Hebrew Israelites who also go by the name of "the Original African Hebrew Israelite Nation of Jerusalem," Black Hebrews, or Hebrew Israelites are members of an AfricanAmerican community who consider themselves the descendants of the Lost tribes of Israel. According to Salem Encyclopedia, "In its broadest sense, the term "black Jews" includes all persons of African descent in the United States who profess to practice Judaism. Not all such blacks call themselves Jews; believing that the word "Jew" implies whiteness, some prefer to label themselves "black Hebrews" or "Israelites." ${ }^{156}$ Their beliefs, practices and general theology are different from that of modern Jewish communities in Israel and are not particularly

\footnotetext{
${ }^{155}$ Parfitt, Black Jews in Africa and the Americas, 70.

${ }^{156}$ Milton Berman. "Black Jews.” Salem Press Encyclopedia, 2017.

http://http://search.ebscohost.com/login.aspx?direct=true\&db=ers\&AN=96397181\&site=eds-live.
} 
considered Jewish. ${ }^{157}$ The practices of the Black Hebrew Israelites are, however, a blend of both Christianity and Judaism in varying degrees.

The Black Hebrew Israelites are the product of the many encounters of Africans with Judaism. Although some Scholars have traced these encounters to Biblical times, others have argued that its roots are deeply situated in the Trans-Atlantic Slave trade relations, discrimination against African Slaves and Colonial inventions. ${ }^{158}$ According to Robert Weisbord:

It is probable that such identification was based mainly on the fact that Negroes, like the Hebrews of antiquity, had experienced the brutality and indignity of slavery. During the antebellum era, many Mack bondsmen drew an analogy between their own plight and that of the Israelites as described in the Old Testament. Plantation spirituals are replete with Scriptural names and places, and these have been adduced by Ben-Ammi as proof of early awareness by blacks of their Israelite heritage. ${ }^{159}$

However, for the Black Hebrew Israelites, the products of these Black Jewish encounters are in different forms. This may as well include the biblical connection of being part of the twelve tribes of Israel and being members of the Jewish diaspora, the trans-Atlantic Slavery, black Christian identification with the enslaved children of Israel in Egypt, and notably the belief of being descendants of exiled Portuguese Jews. Whichever strand is held unto, it is instructive, that these encounters have produced a religious movement distinct from mainstream Judaism.

Since the American Civil War, the emergence of different religious sects within African American communities have been on the rise. The Black Hebrew Israelites happen to be one out of many of the religious sects, which have emerged with specific claims to Jewish or Israeli

\footnotetext{
${ }^{157}$ Gerald D. Jaynes, Black Hebrew Israelites,(2019) https://www.britannica.com/topic/Black-Hebrew-Israelites

${ }^{158}$ Parfitt, Black Jews in Africa and the Americas, 98.

${ }^{159}$ Robert Weisbord, Israel and the Black Hebrew Israelites, (New York, Journal of Psychology and Judaism, 1975), 27.
} 
identity. ${ }^{160}$ The many Black Jewish groups, which sprung up across the United States in the early twentieth century, were often small and in some cases did not succeed their founders. ${ }^{161}$ According to Merrill Singer, while the life span of many of these African American quasi-Jewish religious sects did not last long, the Black Hebrew Israelites has relatively sustained a tempo that keeps regenerating the interest of America and the mass media. ${ }^{162}$

The uniqueness of the Black Hebrew Israelites is imbibed in its ability to not only expand but in "its attempt to merge Black Jewish identity and religious symbolism with the Return-toAfrica ideology that has been a major theme in African American culture since its inception. ${ }^{163}$ African Americans treated Africa as "a symbolic place — the potential site where a denigrated race could reclaim its dignity." 164

While the Black Hebrew Israelites may be considered a messianic movement, whose identity was born out of a sense of shared divine religious prospects of supernatural deliverance from oppression into a radicalized racial organization whose new racialized African identity was based upon series of Jewish appropriations. ${ }^{165}$ At its early stages, characters and images from the Hebrew Bible influenced the Black Hebrew Israelites. According to Chireau, "interpretations of

\footnotetext{
${ }^{160}$ Chireau, Black Zion, 55

${ }^{161}$ Parfitt, Black Jews in Africa and the Americaas, 92.

${ }^{162}$ Robert Weisbord, Israel and the Black Hebrew Israelites, 27.

${ }^{163}$ Parfitt, Black Jews, 55

${ }^{164}$ Ibid, 86

${ }^{165}$ Ibid, 55
} 
the Hebrew Bible provided the substance for many of the innovations that distinguished AfroChristianity from its white counterparts. ${ }^{166}$

The wheel for the creation of a black counter-theology, which had novel racial structure, and projected blacks into sacred history, was therefore set in motion. It was endlessly replicated, while intentionally maintaining and re-creating biblical characters including Jesus to be blacks. ${ }^{167}$ This form of counter theology persists today, howbeit with renewed effervescence and perceived reality. This saw to renewed efforts to return to Africa, which was considered a sacred place. The Biblically connection of Ethiopia located in Africa made the African American quest for the return to Africa more of a spiritual duty. This saw to the renunciation of American citizenship by a significant number of Black Hebrews in 1967 and the emigration of a large number of Black Hebrews to Liberia temporarily and to Dimona in the State of Israel permanently in $1969 .{ }^{168}$

\section{The Black Hebrew Israelites today}

Today, the Black Hebrew Israelites is a vibrant movement scattered in many cities of the United States and in the land of Israel, particularly Dimona, Israel. Although for those domiciled in Israel, their stay was met with much resistance and has in many ways complicated the already complex question of the Jewish identity and the question 'who is a Jew'? According to Weisbord, for those Black Hebrews domiciled in Israel, they have persistently alluded to the fact that ancient Hebrews were black, a perspective in line with the Black Jewish theology. This

\footnotetext{
166"Chireau, Black Zion, 17.

${ }^{167}$ Parfitt, Black Jews in Africa and the Americas, 69-70

${ }^{168}$ Weisbord, Israel and the Black Hebrew Israelites, 25-26
} 
perception has generated a significant following, even alluding to the idea that the actual Jews of modern Israel are impostors. ${ }^{169}$

Notwithstanding the friction, which these claims have generated over the years, many Black Hebrews still hold onto the suggestion that the Jews who occupy the land of Israel are not of the seed of Abraham. Unfortunately, for them, this racial narrative has set them on a collision course with many Jews and Christians alike. This theology is therefore considered somewhat pervasive and offensive to mainstream Christian theology ${ }^{170}$ Although the treatment of the Black Hebrews particularly in Israel have been ambivalent, there persists a high level of friction between the Jews and the Black Hebrew Israelites.

According to an article published by Haertz, a Hebrew news media outfit, today, the African Hebrew Israelites domiciled in Israel have weathered the storm of racism and poverty and have remained in Israel despite these difficulties. They have established a vibrant community, which significantly contributes to the Israeli community, in the military and even in sporting events. ${ }^{171}$ It may therefore appear, that they have been accepted. However, some Israelis still consider them outsiders. Additionally, they are also frequently referred to as Kushim-a racial slur for black people. There appear to be varying levels of friction between the Black Hebrew Israelites and the Israelis. Even those who were accepted into the army, regularly get to be treated unequally when compared with their Israeli counterparts, since majorities of them have surreptitiously been prevented from becoming citizens.

\footnotetext{
${ }^{169}$ Parfitt, Black Jews, 69

${ }^{170}$ Weisbord, Israel and the Black Hebrew Israelites, 34.

${ }^{171}$ Andrew Esenten, The African Hebrew Israelites Want to be Part of Israel, but Israel won't commit, (2017), https://www.haaretz.com/opinion/.premium-israel-give-the-african-hebrew-israelites-citizenship-1.5461503
} 
Recently in 2012, some members of the Black Hebrew Israelite community decided to undergo some sort of formal conversion to Judaism. Various groups of Jewish institutions duly acknowledged this move both in Israel and in the United States. However, most members of the Black Jewish community considered any attempt at converting them to be another scheme by white supremacists rather than a return to the faith that was originally theirs and a black religion all along. They, therefore, perceive any kind of formal conversion as one done by impostors. ${ }^{172}$

The Black Hebrew Israelites in the United States practice a unique form of Judaism. Although similar to mainstream Judaism, it is a blend of Old Testament oriented practices combined with Christianity. They hold services on Saturdays, observing the Sabbath, and mostly, practice Jewish dietary laws and rituals. Although these practices are not particularly aligned within the various Black Hebrew Israelites beliefs as they vary considerably, they, however, share common characteristics, which are in tandem with African American form of Judaism, which is based on social, political and civil rights-related orientation. ${ }^{173}$ They creatively make use of recognized Jewish traditions and rituals to create their version of Judaism and identity. They do not hesitate to appropriate Jewish history all over the world to suit their experiences and to facilitate the construction of Jewish hybrid identity. ${ }^{174}$

The Black Hebrew Israelites attempt to observe various Orthodox ritual traditions, although they add their themes to the dressing, music, and culture. They also recreate African versions of how ancient Israelites dress, by wearing white and purple gowns, alongside silk

\footnotetext{
172 Milton Berman. "Black Jews.” Salem Press Encyclopedia, 2017. http://http://search.ebscohost.com/login.aspx?direct=true \&db=ers\&AN=96397181\&site=eds-live.

${ }^{173}$ Chireau, Black Zion, 28

${ }^{174}$ Ibid, 28.
} 
drapes. They eat only kosher foods, hold services on Fridays and Saturdays, and celebrate Jewish holidays, especially the Passover festival, which has particular resonance for African Americans. Others include Christian elements and symbols in their services. Some who call themselves black Hebrews or Israelites, and try to reconstruct the primitive Judeo-Christianity of the first century, asserting that Jesus is the Messiah of the Jews but rejecting most Christian theology.

The major thrust of this African American movement is centered on the belief that they are descendants of the children of Israel. They are known for holding unto quite extreme narratives, which directly expunge the 'white' Jews from the land of Israel while placing themselves within the context of most of these narratives. In a recent article in an online magazine, the Black Hebrew Israelites were described as "black supremacists" who consider themselves superior to the white race, particularly the Jews whom they believe to be impostors. ${ }^{175}$ This has given rise to various forms of appropriation and adaption of Jewish history.

One aspect of Jewish history, which the Black Hebrew Israelites appropriate and have come to consider as their story, is the Inquisition. Many members of this group have described this important portion of Jewish history, which took place in the Iberian Peninsula, particularly in Spain and Portugal, as the 'black inquisition.' In many ways, their appropriation of Jewish history transcends the narratives of ancient Israelites in the Bible. For them, Jewish history comes in a package, which they have appropriated excluding the events of genocide and the Holocaust.

\footnotetext{
175 SPLC Intelligence Report, Racist Black Hebrew Israelites becoming more militant, (2008) https://www.splcenter.org/fighting-hate/intelligence-report/2008/racist-black-hebrew-israelites-becoming-moremilitant.
} 


\section{African American Appropriation and the case for a Black Inquisition}

The concept of perceiving history, economics, and politics from an African perspective has consistently been of interest to Africans and African Americans since the first half of the nineteenth century. ${ }^{176}$ Since that time, there has been a significant rise in literature, which amplify the African past and emphasized on the role, which Africans and African Americans played or are purported to have played in the history of world civilization.

This Afrocentric phenomenon caught up with African Americans in the United States and the Caribbean in the late eighteenth and nineteenth century. It was identified earlier, that the creation of various hybrid Jewish identities in Africa and the Americas could be either traced to colonial conspiracies propagated to enable the colonizers successfully gain access to the psychology of the colonized for domination, for racial discrimination justifications, and religious and messianic fervor. It was noted earlier, that African Americans appropriated these divine stories as a way to psychological deal with the pains of slavery and discrimination or some sort of counter theology to address the Hamitic theory of white supremacy.

These appropriations subsequently crystalized to the formation of black religious groups, which tilted towards an Afrocentric worldview. Notably is the African American community, particularly the Black Hebrew Israelites who among other narrations have appropriated the history of the Spanish Inquisition and the story of the Sephardic Orphans of São Tomé as their own. Although these appropriations have led to various conflating theories regarding African American claims to ancient Israel and Jewish ancestry. It has gathered a significant following among African Americans.

\footnotetext{
${ }^{176}$ Parfitt, Black Jews in Africa and the Americas, 80.
} 
The earliest history of these appropriations by African Americans is unknown. However, it can be traced to a series of writings and books published in the modern period, which circulated and gained traction among African Americans, especially in the 1800s and early 1900s. During this period, various African American religious groups were founded upon various Afrocentric ideologies and subsequent claims to Jewish ancestry. Worthy of note is Rabbi Ford's insistence that Judaism was originally African and that contemporary West Africa was not only Semitic but also Mosaic. Also, that, it was the Romans who "severed Africa completely from the recognized Jewish economy." ${ }^{177}$ According to Ford on the history of his Beth B'nai Abraham congregation, he writes:

Here is a very significant fact, that those of us here never even had a Caucasian teacher to instruct us into the principles of our faith up to the present, this alone is evidence that as regards our faith as original. However, we ourselves do not hasten to take advantage of the foregoing as a proof of our Jewish originality, because although our teaching came through our parents, our parents might have had theirs from our Caucasian brethren with whom they suffered side by side during the horrible years of the Christian Inquisition and the Christian slave trade to Africa, the West Indies, and South America. This is a fact that can be proven by us. It is not customary for Caucasian (is that a nice name) Hebrew brethren to admit that behind the African mind there are originally the roots of Hebrew culture but this is our contention and although in ritualism we may differ and perhaps be found wanting in heart and in custom we are Hebraic and nothing else. ${ }^{178}$

Ford and his congregation believed, these 600 Sephardic orphans eventually intermarried with Africans and passed on their names and Jewish practices to their children. ${ }^{179} \mathrm{He}$ believed that African Americans were the descendants of these exiled Sephardic children. Rabbi Ford being one of the pioneers of the many African American religious movements during the 1800s

\footnotetext{
${ }^{177}$ Dorman, Chosen People, 190-191

${ }^{178}$ Ibid, 190-191

${ }^{179}$ Ibid, 125.
} 
disseminated these Afrocentric ideas to his congregation and the African American community. He wrote regarding the history of the African American Jewry:

In one instance a shipload of Sephardim Jewish youths over 600 of them exiled from Spain where shipwrecked on St. Thomas and the Virgin Islands, now owned by the United States. They never left there. They grew up, intermarried with the Africans, propagated and their descendants bear their names, customs, and blood to the present day. These are facts. ${ }^{180}$

It is important to note that these ideas were not particularly unique to Ford and his congregation. They were a product of various books written during the European renaissance attempting to account for some sort of Jewish presence in Africa, as well as books written in an attempt to debunk various Eurocentric narratives about blacks being an inferior race, and Jews to be in eternal servitude. ${ }^{181}$ These narratives not only depicted Portuguese Jews as blacks but also described the Sephardic children who were snatched from their mothers as blacks. Apparently, this resonated with African Americans, as can be seen in Ford's writings. They have however been passed down from generation to generation by a significant portion of African Americans and are constantly highlighted and popularized by the Black Hebrew Israelites. The corpus of literature which the Black Hebrew Israelites draw this notion, are often described as accurate, due to how long they were written. These works have become inerrant for the Black Hebrew Israelites, and they do not hesitate in transmitting it through the internet and a plethora of books, written by African Americans themselves.

One such works, which suits the African American narrative and is consistently cited by the Black Hebrew Israelites, designates the Jewish race to be black. In Richard Owen's 'On the

\footnotetext{
${ }^{180}$ Dorman, Chosen People, 190

${ }^{181}$ Parfitt, Black Jews in Africa and the Americas, 80.
} 
Classification and Geographic Instruction of the Mammalia,' he writes regarding the effect of climatic conditions on the color of the Jews. He states that for 1800 years, the Jewish races has traversed the different latitudes and climates. Despite their exclusivity regarding mixing with other races, had acclimatized to the weather conditions of the various geographical locations they were domiciled. Owen, however, describes the Jews who remained in the Middle East around the valleys of Jordan in the Middle East as:

A low race of people, and described by trustworthy travelers as being as black as any of the Ethiopian races. Others of the Jewish people, participating in European civilization, and dwelling in the northern nations, shew some instances of the light complexion, the blue eyes, and light hair of the Scandinavian families - we are thus led to account for the differences in color, by the influence of climate, without having to refer them to original or specific distinctions. ${ }^{182}$

Similarly, the Black Hebrew Israelites also draw their conclusions of Black Jewishness, from Lieutenant Don Isidro de Posadillo's 'The Suez Canal.' It was stated regarding the expelled Jews of Portugal, that the land of St. Thomas where they were expelled to was "populated by mulattoes descended from the Jewish exiles and Anglo women. It is possible that the Jewish type of character noticed at the Gabun and Luango may have originated from this source." 183 Also in Wilson Armistead's 'A Tribute For the Negro", like Owen, he attempts to analyze the effects of the conditions of the weather in the transformation of a white person to become black. In his work, he cites Oldendorp, who as mentioned earlier was one of the characters involved in the imposition of Jewish identities on the Igbo of Nigeria. Armistead posits that:

There are black races in Africa among the genuine descendants of emigrants of ArabiaA remarkable fact in the history of Luango, in the empire of Congo, is that the country,

\footnotetext{
${ }^{182}$ Richard Owen, On the Classification and Geographic Instruction of the Mammalia, 96,97

${ }^{183}$ Isidor Posadillo, "Various." The Nautical Magazine and Naval Chronicle for 1845. (Cambridge University Press, 2013), 529.
} 
according to a statement which was fully credited by Oldendorp, himself a writer of most correct judgment and of unimpeachable veracity, contains many Jews settled in it, who retain their religious rites and the distinct habits which keep them isolated from other nations. Though thus separate from the African population, they are black and resemble the other Negroes in every respect as to physical characteristics. It is probably in allusion to this case that Pennington, in his "Text Book," says, "the descendants of a colony of Jews, originally from Judea, settled on the coast of Africa, are black. ${ }^{184}$

The Black Hebrew Israelites oftentimes refer to this so-called ethnographic treatise in their assertion of a Black Jewish Heritage in Africa. Ironically, some African Americans who claim Jewish ancestry differentiate themselves from an African, based on the Negro distinction from the ordinary African as held by Armistead.

Similarly, the Black Hebrew Israelites hold unto Sir Harry Johnson's treatise on "The Negro in the New World'. This book was published in 1910 and served as a compendium for the description and analysis of who the Negro was his physical features, geographic location, classification among the Homo sapiens and the Negro's association with other human species. According to Johnson on the classification of a Jew in a footnote, "The Jews are composed of three or four separate racial elements. The Asiatic negroid strain shows itself occasionally in the curly hair, the long eye, and proportions of the skull. The Jewish hybrids with the Negro in Jamaica and Guiana reproduce most strikingly the Assyrian type." 185 The association of the Jew with blackness so to say, particularly in the early 1900s when the book was published is often considered a significant reference to the Jewish ancestry of the African American.

\footnotetext{
${ }^{184}$ Wilson Armistead. A tribute for the Negro: Being a vindication of the moral, intellectual, and religious capabilities of the colored portion of mankind; with particular reference to the African race. (Lulu.com, 1848 ), 67.

${ }^{185}$ Henry Johnson, The Negro in the New World, 27.
} 
Johnson, a British explorer, and botanist had traveled widely around Africa. He spoke many African languages and was a linguist of sorts. However, Johnson was not just an explorer or scholar who published many books on African subjects. He was also a colonial administrator, who was a major player in the scramble for Africa amongst European nations. His many expeditions characterized the conclusion of treaties with local African chiefs in the bid to supersede the Germans in the race for the soul of Africa. ${ }^{186}$

These books alongside many others, which includes John Leighton Wilson's 'Western Africa: Its History, Condition, and Prospects' and Joseph J. Williams' 'Hebrewisms of West Africa,' first published in 1856 and 1930 respectively helped the Black Hebrew Israelites to demonstrate the presence of Black Jews in West Africa. ${ }^{187}$ Although, while Wilson's book identifies Jewish practices in Guinea, Williams identified the Ashanti of Ghana as Hebrews, emphasizing certain Jewish religious practices such as circumcision, marriage rites, purification laws, and ceremonial ablutions. It is important to note, however, that both groups are geographically located in West Africa.

The Black Hebrews harp on this supposed Jewish existence in West Africa to demonstrate how the trans-Atlantic Slave trade devastated the various Hebrew communities in West Africa. ${ }^{188}$ They also draw a connection between these scattered Hebrew communities in West Africa with the Sephardic Orphans of São Tomé while some argue that these orphans intermarried with other freed Africans. ${ }^{189}$ Others insist that these Sephardic Orphans simply re-

\footnotetext{
${ }^{186}$ Casada, James A. Sir Harry Hamilton Johnston: a bio-bibliographical study. Vol. 18. Basler Afrika Bibliographien, 1977, 1.

${ }^{187}$ Elias Jones, Black Hebrews: The Quest for Authentic Identity, 47.

${ }^{188}$ Ibid, 47.

189 Jacob Dorman, Chosen People, 189.
} 
connected with their Hebrew kin around West Africa. One particular African American Writer Rudolph Windsor argues that the Sephardic Orphans subsequently migrated to the Angola coast and the West coast of Africa between 1484 and 1499. ${ }^{190}$.

According to Windsor, a scholar closely associated with the Black Hebrew Israelites, the Sephardic Jews were black and were referred to as black Portuguese. In his book "From Babylon to Timbuktu," he cited R.H.M. Elwes' description of Baruch Spinoza, who was described as "middle-sized, good features, skin somewhat black, black curly hair, long eyebrows of the same color. ${ }^{191}$ Windsor also narrated the story of the Sephardic Jews, identifying that they were" seven hundred black children-- ruthlessly taken from their parents in Portugal and transported to the island of São Toméoff the west coast of Africa." ${ }^{192}$ Although he believes that, more black Portuguese Jews were deported than has been accounted.

Windsor argues that the black Jews of São Tomé migrated to the Angola coast between 1484 and 1499. He, therefore, compares their fate to African Americans, concluding that their descendants were subsequently captured and enslaved in the Americas. According to him, there are unifying factors, which point to their Hebrew heritage. This includes their inability to remember their original nationality in Africa since they came from Portugal. ${ }^{193}$ The Black Hebrew Israelites also teach that due to the policies of the slave masters, many African Americans as descendants of victims of the trans-Atlantic slave trade cannot remember their

\footnotetext{
${ }^{190}$ Rudolph Windsor, From Babylon to Timbuktu, 125

${ }^{191}$ Ibid, 116.

192 Ibid, 124.

${ }^{193}$ Ibid, 125.
} 
Hebrew heritage. ${ }^{194}$ According to Windsor, who argued that the Sephardic Orphans migrated to the west coast of Africa from São Tomé, he added, "the black Hebrew were snatched from the west coast of Africa and sold into captivity. ${ }^{195} \mathrm{He}$ appears to explicitly tie the fate of the Sephardic Orphans of São Tomé to the African Americans. Also, in response to a post made by one Nana Kofi on a Black Jewish online website, Debbi a commentator, stated that;

The Atlantic Slave Trade was nothing but Hebrews. We were scattered to the four corners of the earth like the bible says. The blacks in America are from the tribe of Judah. The whites claiming to be Jews are -of-the Synagogue of Satan. Revelation 2:9 and 3:9 Say that. I thank my Lord for a waking me. ${ }^{196}$

Similarly, however, with some historical modifications, Edgar Shaw, an African American writer who also propagates Afrocentric ideas, argues that the Jews who fled the Inquisition of Portugal and Spain were blacks. According to Shaw, "It is estimated that over 100,000 Jews departed from Spain and Portugal during the persecutions and expulsion. Some of these Jews went to northern and western Africa. The black Jews would innocently go to African countries most of all because of less persecution and they could semblance themselves easily among blacks." 197

Like Windsor, Shaw gives a detailed physical description of the Portuguese Jews Baruch Spinoza, in all his 'blackness,' alluding to the fact that the Portuguese Jews were black. He also points out "seven hundred black Hebrew children were ruthlessly taken away from their parents in Portugal and transported to the Island of São Tomé off the west coast of Africa." He concludes

\footnotetext{
${ }^{194}$ Elias Jones, Black Hebrews: The Quest for Authentic Identity, (Howard University ,1988), 47.

${ }^{195}$ Rudolph Windsor, From Babylon to Timbuktu, 133.

${ }^{196}$ Nana Kofi, The list of African tribes who are descendants of the Hebrew Israelite nation, (Rasta Livewire, 2016), 04/01/19.

${ }^{197}$ Edgar Shaw, The Untold Story, 84.
} 
that the slave ships deported slaves from these coastal areas of West Africa to the Americas, specifically identifying Brazil as one of the destination ports. ${ }^{198}$

According to Shaw, countless black Jews of Portugal, São Tomé and Angola who were victims of the Portuguese persecution and Inquisition were sold into slavery during the Trans Atlantic slave trade that lasted for over 400 years. Shaw also identifies the inability of some groups in West Africa to identify their origins. He proposes that this peculiar similarity to African Americans is a pointer to similar Hebrew Origins. A commentator on the Rasta Livewire website confirmed this widely held belief amongst black Hebrews. According to Set Apart Niqyah, "All that have ancestors that were slaves are Hebrew Israelites. Therefore, it is a whole lot of us, Blacks that were scattered across the -four- corners of the earth. We cannot trace our people Past America. We are a large and mixed multitude -of-people."199

For him, the geographical origin of these black Jews is the land of Israel. However, he alludes that they were cut off and expelled from the land by the Romans, upon taking over Palestine. ${ }^{200}$ Shaw examines the words of the Prophet Amos, in Amos 9:7 to justify his claims, which says, "Are ye not as children of the Ethiopians unto me, O children of Israel? saith the LORD. Have not I brought up Israel out of the land of Egypt? and the Philistines from Caphtor, and the Syrians from Kir?" According to Shaw this means that the Israelites were first Ethiopian, originally living in the land of Ethiopia. ${ }^{201}$

\footnotetext{
${ }^{198}$ Ibid, 84.

${ }^{199}$ Nana Kofi, The list of African, (Rasta Livewire, 2016), 04/01/19.

${ }^{200}$ Edgar Shaw, The Untold Story, 89

${ }^{201}$ Ibid, 47.
} 
Similarly, Ronald Dalton's "From Hebrews to Negroes," a three-volume book, and a compendium of sorts on the history and identification of black Jews. Dalton, an African American writer and a practicing Black Hebrew Israelite himself, insists that there appears to be a cover-up in the non-description of the expelled Sephardic orphans as non-Africans. Also drawing his conclusion from Olderndorp's ethnography and Maurice Fishberg's "Jews, Race, and Environment," he posits and re-emphasizes the presence of black Jews and evidence of the practice of Judaism in West Africa. ${ }^{202}$ According to Dalton, "How is this possible? How are Black so-called "Africans" in Gabon practicing Jewish customs with the knowledge of the language of "Hebrew"? Did anybody teach them this? Did they attend, "Hebrew Schools" staffed by Ashkenazi Jews? The answer is NO! Someone has some explaining to do."203

Dalton posits that King John II of Portugal gave the Black Israelites a chance to convert to Christianity and when they disobeyed, he ordered the abduction of their children who were sent to the Portuguese Islands in the heart of the Bight of Biafra in present-day Nigeria. He asserts that these Black children were forcefully taken to Africa just because they were black, like the Hamitic inhabitants of Africa. He dismisses the narrative that giant lizards ate these children or that they died of starvation, which according to him were spread by Europeans.

The author, however, concludes that Sephardic children were not only black but also used the Atlantic Ocean to sail around Africa to modern Nigeria and subsequently orally spread the story of their experience from Portugal to São Tomé, to meet with their fellow Hebrew Israelite brothers. For Dalton, this explains the presence of Yoruba Jews known as 'Emo YoQuaim' in present-day Nigeria. He also alludes that since the Island of São Tomé is close to some other

\footnotetext{
${ }^{202}$ Ronald Dalton, Hebrews to Negroes: Wake up Black America, (Detroit, G Publishing, 2014), 6. ${ }^{203}$ Ibid, 8
} 
West African coasts, these abducted Children must have swum and made boats to get from the Islands to the mainland of Gabon, Cameroun, Angola, and the Congo. ${ }^{204}$

Dalton insists that this ultimately accounts for the presence of Jewish practices in Nigeria. He identifies the Yoruba and Igbo practicing Jews who are geographically located within and around the Bight of Biafra, where these Sephardic children must have dispersed. In confirming this narrative, Dalton states that:

In 2016, I talked to a Nigerian Pastor in Detroit who was half-Yoruba/half-Igbo and he acknowledged that there were a community of Black Jews in Yorubaland who were considered "strange" by everyone else because they practice a "different religion" with different customs" than the majority of people in Yorubaland (which is either Muslim or Christian). He said that they tell people whenever they ask about their "strange customs," that they are descendants of the Jews in Iberia who were exiled some 500 years ago. What is even more interesting that I found out is that these Black Jews living in Yorubaland known as the "Bnai Ephraim" have the same Y-DNA "E1b1a" as the other people in Nigeria (Igbo, Yoruba, including African-Americans. ${ }^{205}$

Dalton consistently alludes to this narrative as one out of many strands of evidence showing that Jews are Blacks and blacks are Jews. Which consequently confirms that African American ancestors who were forcefully taken from the shores of West Africa into slavery in the Americas are descendants of this stock of black Jews. Although he cites a myriad of books authored by Europeans, he insists on a sort of conspiracy in concealing these portions of history, which affirm the Black Jewish heritage.

Dalton also poses a question as to why Portuguese people will expel white Sephardic Jews to an African Island, off the coast of West Africa. He argues that if this was what really happened, there ought to be overwhelming DNA evidence of white Sephardic Jews in and

\footnotetext{
${ }^{204}$ Dalton, Hebrews to Negroes, 12

205 Ibid, 19.
} 
around São Tomé, at least for the remnants of their offspring. Nevertheless, he asserts that unfortunately, no such evidence can be found in the area. He also argues,

There is no Paternal DNA or Maternal mtDNA found in the black people of São Tomé to suggest that at one time they were all Sephardic Jews - even if white Sephardic Jewish men intermarried or raped Black African women living on the Island of São Tomé, their Y-DNA mark would be imprinted in the DNA of these mulatto children. ${ }^{206}$

According to Dalton, the Catholic Church conspiring with the Spanish, Portuguese and other European monarchies, participated in what he calls white washing and race mixing against the black Jews to cover up these facts. He alludes to a cover-up in the concealment of the identity of black Jews in history, particularly in ancient Israel. Dalton states that:

This is why the Europeans had to commit genocide and slavery on the people of the new world and the Dark Continent. That is why they needed to change the language, the customs, the religion and the identity of the people they enslaved. This is why the Europeans had to allow 2-3 generations to pass before teaching their slaves the Bible. In the same instance, they had to disconnect the older slaves from the younger slaves so that none of their ancestral history or language could be taught. The slaves had to forfeit their language and their heritage before listening to the stories of the Bible from the white man's mouth. If the slave knew his heritage, he would recognize that the Bible was about his ancestors, as most Africans already knew about the Old Testament stories before the European/Arabs set forth in their land. ${ }^{207}$

Like Dalton, many African Americans have arrived at various conflicting theories in demonstrating the narrative that Jews are black. These theories are evident in the different analysis and Afrocentric ideologies used to sustain these Black Jewish ideas. From Bishop Crowdy to Rabbi Ford and subsequently Rabbi Matthew, the identification of Jews as blacks has come in different shades. In Rabbi Ford's 'Short History of the Congregation Beth B'nai Abraham, New York, N.Y,' he acknowledged the symbiotic existence of a white and black

\footnotetext{
${ }^{206}$ Dalton, Hebrews to Negroes, 15,

${ }^{207}$ Ibid, 13
} 
Jewry. According to him, "our teaching came through our parents, our parents might have had theirs from our Caucasian brethren with whom they suffered side by side during the horrible years of the Christian Inquisition." 208

According to J. Dorman, Rabbi Ford "ascribed most of the origins of contemporary Black Hebrews to contact and descent from Sephardic Jews in the West Indies in recent history. ${ }^{209}$ However, Rabbi Matthew's teachings were in line with the idea that Black Jews predate the White Jews. He posits, that the black Jews who should be the ones to teach and validate the authenticity of the white Jews, and not the other way round. ${ }^{210} \mathrm{He}$ was convinced that the ancient Israelites were black people, therefore did not lay much emphasis on the Sephardic connection with the Black Jews as much as Ford did.

Although these divergent ideas, consistently point towards the general belief that African Americans have a strong Hebrew heritage from Africa. According to Pastor Dorsey, an online commentator, "the black slaves in the Atlantic slave trade were Hebrews not Africans; of course some Africans did fall through the cracks because they were black as were the original Hebrews." ${ }^{211}$ These proclamations show that there exists divergent ideological beliefs, which can still be identified among contemporary Black Hebrew Israelites. These differences are not limited to historical details alone, but also seen in how African Americans interpret certain Biblical scriptures and prophecies, by appropriating these prophecies to suit their experiences and narratives.

\footnotetext{
${ }^{208}$ Jacob Dorman, Chosen People, 190

209" Ibid, 125

${ }^{210}$ Yosef Ben-Jochanan, We the Black Jews, (Baltimore, Black Classic Press, 1983) 311-314

${ }^{211}$ Nana Kofi, The list of African Tribes who are descendants of the Hebrew Israelites Nation, (Rasta Livewire, 2016), 04/01/19.
} 


\section{Biblical prophecy as Evidence of African American Sephardic Jewish Heritage.}

As has been identified earlier, many African Americans often interpret the characters of ancient Israel in the Hebrew Bible to be blacks. These ideas are evident in their attempt to dress like ancient Israelites. It was also examined earlier, that these African Americans lay claim to not only the biblical portion of Jewish History but also have appropriated other portions of Jewish history in their attempt to be in harmony with the Jewish identity from antiquity to modern history. This is seen in their appropriation of the story of the abducted Sephardic Jews from Portugal to São Tomé. Notably, in justifying and concretizing their claims to this story, they also make use of Biblical prophecies as evidence to their Jewish identity, particularly as descendants of the Sephardic children.

One particular scripture, which has continuously been appropriated, is Deuteronomy 28:32, which says, "Your sons and daughters will be given to another nation, and you will wear out your eyes watching for them day after day, powerless to lift a hand.” Many Black Hebrews believe that the curses in this chapter apply to the black Jews who must have disobeyed God and were punished for their disobedience. ${ }^{212}$ According to Yoko, an online commentator,

American Negroes are the direct descendants of the tribe of Judah. They are the only people that fit the prophecy of Deuteronomy 28, but still, this has never been taught.... we are a blessed people, I read and study the Torah, I'm by his grace learning the laws and the Elohim's feast days to observe them and keep them. I am Hebrew, not African. I give thanks and praise to the highest Yahuwah and Yahushua for opening my eyes because the time is at hand. Shalom. ${ }^{213}$

Similarly, many African Americans interpret the words of Prophet Jeremiah, which says, "Judah is gone into captivity because of affliction, and because of great servitude: she dwelleth

\footnotetext{
${ }^{212}$ Windsor, From Babylon to Timbuktu, 134.

213 Kofi, The list of African, 04/01/19.
} 
among the heathen, she findeth no rest: all her persecutors overtook her between the straits." According to Windsor regarding this portion of Scripture, the historical evidence indicates that Black Hebrews were sold into captivity from the West coast of Africa. For him, this is evidence that the prophecy was intended for the black Hebrews. ${ }^{214}$

According to Shaw, the invasion of Rome to the land of Israel caused many original black Jews to flee their land. He posits that the rancor caused by this invasion led to blacks Jews who fled to other parts of the world, particularly Spain, to intermix and bear children by other non-Jewish people, which ultimately led to their deportation. He argues, through this intermixing and deportation, many of the slaves traveled to the southwestern coast of Africa. He, therefore, interprets Deuteronomy 28:25, which says, "The Lord shall cause thee to be smitten before thine enemies. Thou shall go out one way against them and flee seven ways before them and shall be removed into all the kingdoms of the earth". For Shaw this prophecy is an evidence, that the Sephardic Jews were black Jews who dispersed and migrated to neighboring countries in Africa and Turkey, clearly operating under the weight of these Biblical curses due to their disobedience. ${ }^{215}$

Consequently, Shaw concludes that "It is certain that many black Jews of Portugal, St. Thome, and Angola were victims of the Inquisition and Portuguese persecution were sold in the slave trade". He posits that the black Jews, who were gathered from the coasts of West Africa after migrating from Spain and Portugal, were taken to various parts of South America as slaves. $^{216}$ Windsor adds that "There are hundreds of thousands of black African Hebrews

\footnotetext{
${ }^{214}$ Winddsor, From Babylon to Timbuktu, 134.

215 Shaw, The Untold Story, 78

${ }^{216}$ Ibid, 79.
} 
scattered throughout the United States-and that--with the revelation of ample historical evidence, the authenticity of these black Hebrews can no longer be questioned."217

In response to the Black Hebrew appropriation of Deuteronomy 28, as a Biblical evidence and prediction of the eventual enslavement of the ancestors of African-Americans, and the inclusion of the story of the Sephardi Jewish Orphans of Sao-Tome in their business of appropriation. Ehan Ever a Black Jewish practitioner who lives in Jerusalem concluded that the Black Hebrew Israelites are misinterpreting Deuteronomy 28. According to Ever, the portion of the Torah which addresses these prophecies as curses for drifting away from God, has no connection whatsoever with the Trans-Atlantic Slave trade experience. He emphasized on the original Hebrew scripture from the Aleppo codex and the Samaritan Torah, which says that Jews will sell themselves to people, but no-one will buy them. He insists that this is not applicable to African Americans being that they were sold and that people actually bought them. ${ }^{218}$ On the other hand, Dalton a Black Hebrew rejects this idea. He argues that there exist years of historical manipulation, and as such most of what is described as original Hebrew has been doctored to suit Eurocentric narratives. ${ }^{219}$

On the other hand, Windsor argues that just like history, prophecy always repeats itself. He points out that the enslavement of the Black Hebrews from the west coast of Africa after their deportation from Portugal as part of these prophecies. ${ }^{220}$ Shaw also posits that God gave the

\footnotetext{
${ }^{217}$ Windsor, From Babylon to Timbuktu, 134

${ }^{218}$ Ehav Ever, "Response to Hebrew Israelite Comments". Filmed (December, 2011) You Tube video, 7:58. Posted (December 2011). https://youtu.be/2tP1izqCAnw.

${ }^{219}$ Kada Yah Yisrae'el, "Hebrews to Negroes-Chapter 1 dvd preview", Filmed, (December, 2014) You Tube video, 1:37:38. Posted (December 2014). https://youtu.be/7JHi_iWsBlQ.

${ }^{220}$ Ibid, 133.
} 
books of the Bible to his prophets and that it is certain that this message of the Lost Tribes of Israel was given to the Lord's chosen people (Black Jews) "who were finally dispersed to Africa, the United States and perhaps the whole world, according to Biblical prophecy". ${ }^{221} \mathrm{He}$ argues that these scattered tribes were mixed through their travels, forgetting their Hebrew roots, but continued their Hebrew practices. ${ }^{222}$ According to him, there appears to be a grand conspiracy to hide the information of the real roots of the remnants of the lost tribe whom God punished for their sins and disobedience, even though he loved them.

The appropriation of not just Biblical stories, prophecies and characters, but Jewish history has shaped and sustained the African American community in more ways than can be imagined. The internalization of these divine and historical events has guided many African American leaders, in performing their spiritual and political obligations. This is evident in the role it played during the civil rights movements. For many African Americans, these appropriations are not just for religiosity but are transcendental. How this brand of Israelophobia can be managed without confrontations and anti-Semitism is an issue, which requires much study and a balanced approach.

This Chapter set out to find the connection between African Americans and the Jews. On this quest, it identified a crisscrossing of Judaic ideas between Africa and the Americas. It identified the substantial influence of the colonists in spreading the seeds of Jewish identity in Africa, as well as in the Americas. It also highlighted the fact that, although these ideas were not initially meant for African Americans, they were however systematically spread around the United States by messianic African American preachers. This section, therefore, examined the

\footnotetext{
${ }^{221}$ Shaw, The Untold Story, 78

${ }^{222}$ Ibid, 80.
} 
emergence of the Black Hebrew Israelite movement in the United States, and how the experiences of the Jim Crow Laws and Back to Africa ideology helped to deeply enmesh a wave and memory of Jewish identity, which persists. It also examined how the Story of the Sephardi Jewish Orphans became a ready-made meal for African American consumption in the performance of their identity projects. 


\section{CONCLUSION}

\section{Summary}

As was discussed in the first part of this work, this study set out to show how the story of the exile of the Sephardic Jewish Orphans of São Tomé has influenced the creation and performance of Jewish identity among some African Americans. It attempted to use various African American narratives as a watershed in recognizing the intellectual concept of Afrocentrism and collective memory in the appropriation and reconstruction of Jewish history, particularly the Jewish experience in the Iberian Peninsula, which led to the Inquisition.

This study also highlighted the uniqueness of the Story of the Sephardic Jewish Orphans of São Tomé and how some African Americans in their identity performance projects have appropriated this story. The theory of Collective memory was discussed in this work, as a process in which African Americans were able to appropriate this Story because of their experiences and encounters with Slavery and dehumanization. In essence, the Story of the Jewish Orphans resonates with the memory of the trans-Atlantic slave trade by many African Americans.

In addition, it was also discussed that the appropriation of this portion of Jewish history is one of the ways, in which the Black Hebrew Israelites hold unto a Jewish identity. This has metamorphosed to the creation and practice of their own form of Judaism. It was also identified, that this little known story has become, to many African Americans, a major strand of evidence in which they express the role of Africans in western civilization. This process was identified as Afrocentricity, a concept made popular by Molefi Asante.

The idea that Africans were not mere onlookers in the process of world civilization has become currency for various identification and appropriation projects. This work however traced 
the appropriation of the story of the Sephardic children to Jewish existential ideas that either emanated from Africa or from the experiences of slavery by African Americans or other victims of the slave trade in the Caribbean. This ingenious method of revolt by African Americans saw to their Jewish identification and subsequent practice of Judaism. To concretize these beliefs, many African Americans paid heed to the ideas that there existed in Africa various groups of Israelite remnants who were considered remnants of the lost tribes of Israel.

This work nonetheless, highlighted the influence of British colonists on the literature, which became popular at the height of curious self-identification projects of African Americans as Jews in the 1880's. These ideas spread by the colonists all around the colonized world had its own apocalyptic fervor, which was identified by Daniel Lis as 'Christian Millenarianism'. The colonists believed that the conversion of the lost tribes of Israel, which they believed to be in Africa, would precipitate the second coming of Christ. ${ }^{223}$ Various examples of African groups who have held unto these Jewish ideas disseminated by literature mostly enabled or sponsored by colonists abound, all across Africa.

Notably is the Jewish connection to the Falasha of Ethiopia and the Igbo of Nigeria. Many African American groups including the Black Hebrew Israelites constantly identify with the perceived Jewishness of these African tribes and many others, as evidence of the presence of Jewish groups in Africa, thereby tracing their African descent to these supposed African Jewish groups in Africa. The narrative which has become gospel for many African Americans who identify with the Jewish religion, is that the Sephardic Children who were expelled from Portugal to São Tomé, where indeed blacks. They believe that there is a grand conspiracy to white wash the race of these children. They take this narrative a step beyond the Sephardic Jews of São

\footnotetext{
${ }^{223}$ Lis, Ethiopia Shall Soon, 22.
} 
Tomé, insisting that the Inquisition was a scheme to exterminate not just the Jews but also the Jews who were Blacks, hence the use of the term 'black inquisition'.

In line with the narrative that the Inquisition was perpetuated against the blacks, some members of the Black Hebrew Israelites, have referred to the physical description of Jews as blacks in literature written in the modern era. Notably, is the description of Baruch Spinoza, an acclaimed Portuguese Jew, who was described as 'black' in earlier literature. According to Deestee, a go to online resource for African Americans, one user pointed out, "I Luv the truth original Spanish Hebrews are Black." This was in response to the literal description of Spinoza as black, as described by R. H. M. Elwes ${ }^{224}$ Other sources include Francois-Maximilian Mission's description of Jews as Black and swarthy as well. According to Mission;

Tis also a vulgar error that the Jews are all black; for this is only true of the Portuguese, who, marrying always among one another, beget Children like themselves, and consequently the Swarthiness of their complexion is entail'd upon their whole Race, even in the Northern Regions. But the Jews who are originally of Germany, those, for example, I have seen at Prague, are not blacker than the rest of their countrymen. ${ }^{225}$

These descriptions of Jews as blacks which are often emphasized upon by Black Hebrews are exhaustive. It was discussed earlier that some African Americans believe that the Sephardic children who were abducted and taken to São Tomé subsequently dispersed to other parts of Africa, where they met with other Africans and Jewish communities which already existed in

\footnotetext{
${ }^{224}$ https://destee.com/threads/a-graphic-description-of-the-portuguese-jew-named-baruch-spinoza.82886/ Accessed February 14,2019.

${ }^{225}$ Francois-Maximilian Mission, A New Voyage to Italy (London, 1714), 2, 139; cited by Jonathan Schorsch. 2005. "Blacks, Jews and the Racial Imagination in the Writings of Sephardim in the Long Seventeenth Century." Jewish History 19 (1): 115. doi:10.1007/s10835-005-4360-0. https://www.jstor.org/stable/20100948.
} 
Africa, thereby alluding to the Sephardic Jewish children being black and easily mingling with other black Jews in Africa. ${ }^{226}$

Although the idea of a colonial conspiracy theory for the spreading of the seeds of Jewishness all across Africa has been largely ignored by many African American Jewish adherents and Africans alike, the prospects of its validity are clear. In view of the African Jewish connections and the many conspiracy theories which are not particularly substantiated. It is clear that many African American groups, which identify with the Jewish religion, are poised to validate their Jewish identity. This concept of Afrocentricity best explains this effervescence. The uprooting of the African American from his heritage has provided a lacuna, which has best been expressed in an ideological and religious revolt situation. The story of the Sephardic Jewish Orphans happens to suit the Afrocentric narrative, over the Eurocentric considerations.

\section{Limitations and Future Directions}

It is noteworthy that the references constantly cited by many African American groups regarding the color of the Jews in antiquity and in the Iberian Peninsula are difficult to ignore. Various Scholars have attempted to explain the role of the derogatory use of blackness to describe Jews by writers of the modern era. According to Jonathan Schorsh;

Early Modern Catholic Iberian discourse generally scorned Jews and linked them, implicitly and sometimes explicitly, with denigrated Africans, or Blacks. Marginalized and often persecuted, conversos and Sephardim of the sixteenth through the eighteenth century resorted to hegemonic discourse about Blacks to construct their own identity. Central to Sephardic discourse about Blacks was its redemptive logic. ${ }^{227}$

\footnotetext{
${ }^{227}$ Jonathan Schorsch. 2005. "Blacks, Jews and the Racial Imagination in the Writings of Sephardim in the Long Seventeenth Century." Jewish History 19 (1): 109. doi:10.1007/s10835-005-4360 0. https://www.jstor.org/stable/20100948.
} 
Similarly, Lindsey Kaplan suggests that, "The inconsistency with which Jewish blackness is deployed may account for the failure to take it seriously and analyze its development". $\mathrm{He}$ argues that these inconsistencies express varying depictions and as such, only one narrative should not be emphasized upon. ${ }^{228}$

Despite these attempts, the perception of Jews as blacks in metaphorical terms is yet to be accepted by some African American groups. On the one hand, the description of Jews as 'swarthy and black 'in various Iberian literature other than the skin tone of the European Jews, is yet to fizzle out. Curiously, the story of the Sephardic Orphans of São Tomé aids the AfricanAmerican narrative, since history plants these children in the heart of Africa. Perhaps more research needs to be invested in clearing the air on this subject.

This study shed light on this dark part of history, which very little scholarship has been invested in enhancing its impact on not only Jewish studies, but world history. The mere fact that there was a reverse Trans-Atlantic Slave transaction from Europe to Africa and not the other way around, speaks volume to the huge impact the Story of these Orphans hold. Long before any African was transported from the west coasts of Africa, these little-known children had already been exploited for forced labor and psychological degradation.

Furthermore, in an era of globalization and trans-border and immigration crisis all over the world. This story speaks to the fact that when history and the lessons which ought to be gleaned from such historical events are ignored, mistakes are bound to be repeated. On the other hand, the role of Africans in history needs to be studied and examined for the purpose of inclusivity in history and the role Africans played in World civilization. The famous Aristotle

\footnotetext{
${ }^{228}$ Lindsey Kaplan, The Jewish Body in Black and White in Medieval and Early Modern England. (Philological Quarterly 92, 2013), 41-65
} 
once postulated "horror vacui", meaning nature abhors a vacuum. In this case, the vacuum doesn't imply a physical space, but a historical and emotional lacuna which needs to be filled to placate not only the abduction of Africans into slavery in the Americas, but also the abduction of the Sephardic children of São Tomé. 


\section{BIBLIOGRAPHY}

Afigbo, Adiele Eberechukwu. Nigerian history, politics and affairs: the collected essays of Adiele Afigbo. Africa World Press, 2005.

Appiah, Anthony. In my father's house, Africa in the philosophy of culture. OUP USA, 1993.

Asante, Molefi. Afrocentric idea revised. Temple University Press, 2011.

Asante, Molefi, Afrocentricity New Jersey, Africa World Press Trenton, 1988.

"De-Westernizing Communication: Strategies for Neutralizing Cultural Myths." In DeWesternizing Communication Research, 34-40: Routledge, 2010.

Barnett, Michael. Rastafari in the new millennium: A Rastafari reader. Syracuse University Press, 2014.

Basden, George Thomas. "Niger Ibos: A Description of the Primitive Life." Customs and Animistic Beliefs etc. of the Ibo People of Nigeria (1966).

Ben-Jochannan, Yosef. We the Black Jews. Vol. 1. Black Classic Press, 1993.

Berlin, Ira. "African immigration to colonial America." History Now. The Gilder Lehrman Institute of American History. Retrieved February 13 (2005): 2010.

Bontemps, Arna Wendell, ed. Great slave narratives. Vol. 20. Beacon Press, 1969.

Bracey, Earnest N. Prophetic insight: The higher education and pedagogy of African Americans. University Press of America, 1999.

Bruder, Edith, and Tudor Parfitt, eds. African Zion: Studies in Black Judaism. Cambridge Scholars Publishing, 2012. 
Casada, James A. Sir Harry Hamilton Johnston: a bio-bibliographical study. Vol. 18. Basler Afrika Bibliographien, 1977.

Chawane, Midas. "The development of Afrocentricity: A historical survey." Yesterday and Today 16 (2016): 78-99.

Chireau, Yvonne, and Nathaniel Deutsch, eds. Black Zion: African American Religious Encounters with Judaism. Oxford University Press, 1999.

Chukwuokolo, J. Chidozie. "Afrocentrism or eurocentrism: The dilemma of African development." OGIRISI: A new journal of African studies 6, no. 1 (2009): 24-39.

Jadin, Louis, and Joseph Cuvelier. L'Ancien Congo: d'après les archives romaines: 1518-1640. Académie royale des sciences coloniales, 1954.

Dorman, Jacob S. Chosen People: The Rise of American Black Israelite Religions. Oxford University Press, 2016.

Equiano, Olaudah. The interesting narrative of the life of Olaudah Equiano. Broadview Press, 2001.

Falola, Toyin, and Raphael Chijioke Njoku, eds. Igbo in the Atlantic World: African origins and diasporic destinations. Indiana University Press, 2016.

Garfield, Robert. "A Forgotten Fragment of the Diaspora: the Jews of São Tomé Island, 14921654." The Expulsion of the Jews—1492 and after, New York, Garland Pub (1994): 73-87.

George, J., and Sefa Dei. "Afrocentricity: A cornerstone of pedagogy." Anthropology \& Education Quarterly 25, no. 1 (1994): 3-28. 
Gerber, Jane S. Jews of Spain: A History of the Sephardic Experience. Simon and Schuster, 1994.

Green, Tobias. "Further considerations on the Sephardim of the Petite Côte." History in Africa 32 (2005): 165-183.

Halbwachs, Maurice. On collective memory. University of Chicago Press, 1992.

Hull, Richard. Jews and Judaism in African history. Markus Wiener Publishers, 2009.

Ibrahim, Farah A., and Jianna R. Heuer. Cultural and social justice counseling. Geneva: Springer, 2016.

Jaynes, Gerald D. Encyclopedia of African American Society. Vol. 1. Sage, 2005.

Johnston, Harry Hamilton. The negro in the New World, London, Macmillan, 1910.

Jones, Elias Fanayaye. "Black Hebrews: The Quest for Authentic Identity." The Journal of religious thought 44 , no. 2 (1988): 35-49.

Kaplan, M. Lindsay. "The Jewish Body in Black and White in Medieval and Early Modern England." Philological Quarterly92, no. 1, 2013.

Korieh, Chima J. The Nigeria-Biafra war: Genocide and the politics of memory, Cambria Press, 2012.

Lefkowitz, Mary. Not out of Africa. Рипол Классик, 1998.

Liba, Moshé, and Norman Toby Simms. Jewish child slaves in São Tomé: papers, essays, articles, and original documents related to the July 1995 conference. New Zealand Jewish Chronicle Publications, 2003. 
Lis, Daniel. Jewish Identity Among the Igbo of Nigeria: Israel's" lost Tribe" and the Question of Belonging in the Jewish State. Trenton: Africa World Press, 2015.

Lowenstein, Steven M. The Jewish cultural tapestry: International Jewish folk traditions. Oxford University Press on Demand, 2002.

Mocatta, Frederic David. The Jews of Spain and Portugal and the Inquisition. Longmans, Green, and Company, 1877.

Mustafa, KOÇ, Cultural Identity Crisis in the Age of Globalization and Technology. TOJET : The Turkish Online Journal of Educational Technology, 2006.

Nora, Pierre. "Between memory and history: Les lieux de mémoire." representations (1989): 724.

Ojanuga, Durrenda. "The Ethiopian Jewish experience as blacks in Israel." Journal of Black Studies 24, no. 2 (1993): 147-158.

Oriji, John Nwachimereze. Traditions of Igbo origin: a study of pre-colonial population movements in Africa. Vol. 48. Peter Lang Pub Inc, 1994.

Owen, Richard. On the Classification and Geographical Distribution of the Mammalia: Being the Lecture on Sir Robert Reade's Foundation, Delivered Before the University of Cambridge in the Senate House, May 10, 1859. To which is Added an Appendix" On the Gorilla" and" On the Extinction and Transmutation of Species". John W. Parker and Son, 1859.

Parfitt, Tudor, and Netanel Fisher, eds. Becoming Jewish: New Jews and Emerging Jewish Communities in a Globalized World. Cambridge Scholars Publishing, 2016. 
Schaeffer, Dagmar. Portuguese Exploration to the West and the Formation of Brazil, 1450-1800: Catalogue of an Exhibition. John Carter Brown Library, 1988.

Schorsch, Jonathan. "Blacks, Jews and the racial imagination in the writings of Sephardim in the long seventeenth century." Jewish History 19, no. 1 (2005): 109-135.

Shaw, Edgar. The Untold Story. AuthorHouse, 2004.

Simms, Norman T. 'Devoured by wild animals' Jewish iconography of the serpent. In C. Reddy, \& S. Pub (Eds.), Saundaryashri: Studies of Indian History, Archaeology, Literature \& Philosophy (Festschrift to Professor AnanthaAdigaSundara) (pp. 946-968). Delhi: Sharada Publishing House, 2009.

Thomas, Mark G., Tudor Parfitt, Deborah A. Weiss, Karl Skorecki, James F. Wilson, Magdel Le Roux, Neil Bradman, and David B. Goldstein. "Y chromosomes traveling south: the Cohen modal haplotype and the origins of the Lemba - the "Black Jews of Southern Africa"." The American Journal of Human Genetics 66, no. 2 (2000): 674-686.

Walvin, James. An African's life: the life and times of Olaudah Equiano, 1745-1797. Weidenfeld \& Nicolson, 1998.

Weisbord, Robert G. "Israel and the Black Hebrew Israelites." Judaism 24, no. 1 (1975): 23.

Wertsch, James V. Voices of collective remembering. Cambridge University Press, 2002.

Windsor, Rudolph R. From Babylon to Timbuktu: A history of ancient Black races including the Black Hebrews. AuthorHouse, 2011. 


\section{INTERNET SOURCES}

Ehav Ever, "Response to Hebrew Israelite Comments". Filmed (December, 2011) YouTube video, 7:58. Posted (December 2011). https://youtu.be/2tP1 izqCAnw.

Kada Yah Y israe'el, "Hebrews to Negroes-Chapter 1 dvd preview", Filmed, (December, 2014) You Tube video, 1:37:38. Posted (December 2014). https://youtu.be/7JHi_iWsBlQ.

https://destee.com/threads/a-graphic-description-of-the-portuguese-jew-named-baruchspinoza.82886/ Accessed February 14, 2019.

SPLC Intelligence Report, Racist Black Hebrew Israelites becoming more militant, (2008) https://www.splcenter.org/fighting-hate/intelligence-report/2008/racist-black-hebrewisraelites-becoming-more-militant

Milton Berman. "Black Jews." Salem Press Encyclopedia, 2017. http://http://search.ebscohost.com/login.aspx?direct=true\&db=ers\&AN=96397181\&site=eds -live.

Molefi Asante, Afrocentricity, 2009, http://www.asante.net/articles/1/afrocentricity/.

Nana Kofi, The list of African, (Rasta Livewire, 2016), 04/01/19. https://www.africaresource.com/rasta/sesostris-the-great-the-egyptian-hercules/black-jewsof-spain-and-benin-guinean-coast-part-1/ 